PRACE GEOGRAFICZNE

zeszyt $148,2017,107-133$

doi: $10.4467 / 20833113$ PG.17.005.6273

Instytut Geografii i Gospodarki Przestrzennej UJ

Wydawnictwo Uniwersytetu Jagiellońskiego

\title{
INTEGRACJA SYSTEMU ZARZĄDZANIA RYZYKIEM POWODZIOWYM I OCHRONA WÓD NA PRZYKŁADZIE DOLINY WARTY MIĘDZY KONINEM A OBORNIKAMI
}

\author{
Renata Graf, Kamil Jawgiel, Jan Łukašewic:
}

\section{Integration of a flood risk management and waters protection system on the example of the Warta Valley between Konin and Oborniki}

Abstract: The aim of the study was the analysis of the integration of a flood risk management and water protection system in a selected section of the Warta Valley with taking into consideration the guidelines of the Water Framework Directive and the Floods Directive. The structure of the valley is comprised within a distance of $201.1 \mathrm{~km}$ by stretches of: an urstromtal, between the towns of Konin and Śrem, and the Warta gorge stretch between Śrem and Oborniki. High environmental values of the valley are shown, related to the presence of conservation areas and, on the other hand, a high flood hazard risk, resulting e.g. from advancing land development in the valley and its low retention capacity. The Integrated Water Resources Management guidelines conception was used in the analysis, inlcuding pointing out the directions of relations between minimizing flood risk and protection of natural values of the Warta River and its valley. Spatial distribution of the flood hazard and risk in the Warta Valley was also analyzed. A detailed analysis covered activities of a technical and non-technical character intended to stop the growth of flood risk. In the field of water conservation, the considered objectives included: achieving and maintaining a good ecological potential of waters or the risk of failing to achieve it, which is determined by a high urbanisation ratio, draining of an open-pit lignite mine, extensive morphological change in the river bed and pollution discharged into the waters from land used for agriculture. The results proved that one 
of the most significant factors directly impacting the environmental condition and ecological potential of the waters is the activity related to flood risk reduction. Potential threats to the functioning of NATURA 2000 areas characterized by high natural values were also indicated.

Keywords: flood risk management, waters conservation, Warta Valley, integration conception

Zarys treści: Celem opracowania jest analiza stopnia integracji systemu zarządzania ryzykiem powodziowym i ochroną wód na wybranym odcinku doliny Warty przy uwzględnieniu założeń Ramowej Dyrektywy Wodnej i Dyrektywy Powodziowej. Strukturę doliny na długości 201,1 km tworzą odcinki: pradolinny, między miastami Konin i Śrem, oraz odcinek przełomowy Warty, między Śremem a Obornikami. Wskazano na wysokie walory środowiskowe doliny związane z występowaniem obszarów chronionych i jednocześnie na wysoki stopień ryzyka powodziowego wynikający m.in. z postępującej zabudowy doliny i jej niskiej zdolności retencyjnej. W analizie wykorzystano założenia koncepcji zintegrowanego zarządzania zasobami wodnymi, wskazując kierunki powiązań między minimalizacją ryzyka powodziowego i ochroną walorów przyrodniczych rzeki Warty i jej doliny. Przeanalizowano rozkład przestrzenny zagrożenia i ryzyka powodziowego w dolinie Warty. Szczegółowej charakterystyce poddano planowane do realizacji działania kierunkowe o charakterze technicznym i nietechnicznym, mające na celu zahamowanie wzrostu ryzyka powodziowego. $Z$ zakresu ochrony wód rozpatrywano cele zakładające osiągnięcie i utrzymanie dobrego potencjału ekologicznego wód lub ryzyko jego nieosiągnięcia, do którego przyczyniają się wysoki stopień zurbanizowania, odwodnienia odkrywkowej kopalni węgla brunatnego, silne zmiany morfologiczne w korycie rzeki oraz zanieczyszczenia odprowadzane do wód z terenów użytkowanych rolniczo. Wyniki wykazały, że jednym z najistotniejszych czynników bezpośrednio wpływających na stan środowiskowy i potencjał ekologiczny wód jest realizacja prac związanych z ograniczaniem ryzyka powodziowego. Wskazano potencjalne zagrożenia dla funkcjonowania obszarów Natura 2000, cechujących się wysokimi walorami przyrodniczymi.

Stowa kluczowe: zarządzenie ryzykiem powodziowym, ochrona wód, dolina Warty, koncepcja integracji

\section{Wstęp}

Struktura i stan systemu zarządzania zasobami wodnymi mają istotny wpływ na stopień jego integracji i możliwość realizacji celów strategicznych związanych m.in. z racjonalnym użytkowaniem i ochroną wód. Rozwój powiązań funkcjonalnych i ekonomicznych wymaga koordynacji procesów społeczno-gospodarczego rozwoju, w tym przedsięwzięć wodnogospodarczych z działaniami na rzecz kształtowania i ochrony środowiska przyrodniczego (Nachlik 2006; Krauze, Wagner 2014; Kowalczak 2015; Mrozik i in. 2015; Graf, Pyszny 2016). Jest to zgodne z zasadą trwałego i zrównoważonego rozwoju, która stanowi jeden z priorytetów strategii Unii Europejskiej „Europa 2020”, wspierającej gospodarkę efektywniej korzystającą z zasobów i przyjazną środowisku. Założenia te znajdują wyraz w Ramowej dyrektywie 
wodnej (RDW - Dyrektywa 2000/60/WE), ustanawiającej podstawy wspólnotowego działania w dziedzinie polityki wodnej i koordynującej prawo odpowiedzialne za gospodarkę zasobami wodnymi, oraz w Dyrektywie powodziowej (DP) w sprawie oceny ryzyka powodziowego i zarządzania nim (Dyrektywa 2007/60/WE). Zawarte w nich przepisy zostały implementowane do prawa polskiego w Ustawie Prawo wodne z 2001 r. z późniejszymi zmianami. Za priorytetowe działania w gospodarowaniu wodami uznaje się: zapewnienie odpowiedniej ilości i jakości wody przy zachowaniu potencjału przyrodniczego, ochronę wód, jak również ograniczenie zagrożeń związanych z wystąpieniem ekstremalnych zjawisk klimatycznych i hydrologicznych (np. powódź, susza). Przy realizacji celów środowiskowych zaspokojenie społecznych i ekonomicznie uzasadnionych potrzeb wodnych gospodarki wiąże się ze zmniejszeniem i ograniczeniem degradacji wód przez osiągnięcie i utrzymanie dobrego stanu lub potencjału ekologicznego wód oraz związanych z nimi ekosystemów (Nachlik 2006). Integracja celów ochrony zasobów wodnych i ochrony przed powodzią zakłada, w porównaniu z dotychczasowym podejściem sektorowym, koordynację działań związanych z ochroną przed powodzią: terenów zalewowych, brzegów koryta rzeki i samego koryta rzeki, jak również ochronę jakości ekologicznej, obejmującej biologię wód, morfologię i własności chemiczne wody.

Problemy związane z występowaniem zagrożenia powodziowego oraz z ochroną zasobów wodnych interpretowane są w rożnych skalach przestrzennych (Grocki, Czamara 2001; Grocki, Eliasiewicz 2001) i czasowych na poziomie ryzyka i rodzaju presji, jak np.: ryzyko powodziowe i ryzyko nieosiągnięcia celów środowiskowych, które dotyczy jednolitych części wód powierzchniowych (jcwp). Konieczność realizacji celów środowiskowych i strategicznych w zakresie polityki wodnej w jednym wymiarze przestrzennym - doliny rzecznej - jest przyczyną pojawiania się obszarów problemowych, w których proces zarządzania zasobami wodnymi wymaga uspójnienia decyzji i pełnej integracji działań (Romanowska, Trocki 2004; Rotko 2006; Kowalczak 2011; Graf, Pyszny 2016). Integracja w zarządzaniu zasobami wodnymi, rozpatrywana na poziomie przestrzennym, funkcjonalnym, ekologicznym i społecznym (Narodowa Strategia Gospodarowania Wodami 2030), opiera się na: równym dostępie do wysokiej jakości zasobów wodnych, wydajnym ich wykorzystaniu dla uzyskania korzyści ekonomicznych oraz zachowaniu równowagi ekologicznej i zdolności systemu przyrodniczego do regeneracji (Global Water Partnership 2000; Wagner i in. 2014; Krauze, Wagner 2014).

Uwzględniając powyższe założenia na wybranym odcinku doliny Warty (Region Wodny Warty - RWW), analizie poddano stopień integracji i realizacji celów strategicznych z zakresu zarządzania ryzykiem powodziowym oraz celów środowiskowych związanych z ochroną wód. Charakterystykę przeprowadzono dla środkowego odcinka biegu Warty (centralna część Niziny Wielkopolskiej) od Konina do Obornik, o długości 201,1 km, obejmującego odcinek pradolinny między Koninem a Śremem 
oraz odcinek przełomowy między Śremem a Obornikami. Z punktu widzenia założeń obu dyrektyw: RDW i DP, wybrany fragment biegu Warty cechuje się wysokimi walorami środowiskowymi, związanymi z występowaniem obszarów chronionych, w tym również obszarów Natura 2000. Cechuje się on jednocześnie wysokim stopniem ryzyka powodziowego, wynikającym m.in. z postępującej zabudowy doliny rzecznej i jej zbyt niskiej zdolności retencyjnej, stanowiącej efekt wzrostu urbanizacji i rozwoju miast zlokalizowanych nad Wartą. Identyfikacja obszarów problemowych w dolinie rzeki związanych $\mathrm{z}$ jednej strony $\mathrm{z}$ istniejącym ryzykiem powodziowym i jego minimalizacją, z drugiej natomiast z zachowaniem i utrzymaniem, poprzez właściwą ochronę wód, ich dobrego stanu lub potencjału ekologicznego, wskazuje na konieczność zachowania pełnej integracji w realizacji celów wodnogospodarczych o różnej randze oraz znaczeniu środowiskowym i strategicznym.

Przeanalizowano rozkład przestrzenny zagrożenia i ryzyka powodziowego na omawianym odcinku doliny Warty. Na tym tle rozpatrywano elementy systemu zarządzania ryzykiem powodziowym oraz cele i działania przewidziane do realizacji w dorzeczu Warty w latach 2016-2021. Zgodnie z Planem zarządzania ryzykiem powodziowym (PZRP dla RWW) stanowią je różnego rodzaju działania kierunkowe i inwestycje o charakterze technicznym i działania nietechniczne. W pracy uwzględniono głównie cele związane z planowaniem działań w zakresie zahamowania wzrostu ryzyka powodziowego oraz obniżenia istniejącego ryzyka powodziowego. W aspekcie założeń RDW (Dyrektywa 2000/60/WE) rozpatrywano natomiast cele zakładające osiągnięcie i utrzymanie dobrego stanu lub potencjału ekologicznego wód do końca 2015 r. Na tej podstawie na wytypowanym odcinku doliny Warty wskazano obszary problemowe, w których realizacja celów środowiskowych i strategicznych wymaga pełnej integracji w ramach systemu zintegrowanego zarządzania zasobami wodnymi.

\section{Metody i materiał źródłowy}

W analizie stopnia integracji systemu zarządzania ryzykiem powodziowym i ochroną wód w dolinie Warty wykorzystano założenia koncepcji zintegrowanego zarządzania zasobami wodnymi (ZZZW), która stanowi podstawę polityki wodnej, realizowanej przez kraje członkowskie Unii Europejskiej (Integrated Water Resources Management - IWRM). System ZZZW zakłada koordynację działań politycznych, gospodarczych i społecznych w zakresie realizacji idei zrównoważonego rozwoju oraz zarządzania wodą, przestrzenią i innymi zasobami w celu zwiększenia korzyści społecznych i ekonomicznych w sposób równorzędny, bez konieczności naruszania równowagi przyrodniczej (Global Water Partnership 2000; Narodowa Strategia Gospodarowania Wodami 2030). 
W analizie stopnia zagrożenia i ryzyka powodziowego oraz działań inwestycyjnych planowanych w zakresie ich ograniczenia i minimalizacji na odcinku doliny Warty między Koninem a Obornikami wykorzystano informacje i dane zawarte w Planie zarządzania ryzykiem powodziowym, opracowanym dla Regionu Wodnego Warty w 2015 r. (PZRP dla RWW). Inwestycje - planowane dla procesu zarządzania ryzykiem powodziowym - są skoordynowane z MasterPlanem dla obszaru dorzecza Odry (2014) oraz z Aktualizacją Planu gospodarowania wodami na obszarze dorzecza Odry (2015-2021) z 2015 r. (KZGW 2015). Analizie poddano m.in. rodzaj działań nietechnicznych i technicznych, w tym zapobiegawczych, ochronnych i przygotowawczych, które powinny się przyczynić do zahamowania wzrostu ryzyka powodziowego, obniżenia istniejącego ryzyka powodziowego oraz poprawy systemu zarządzania ryzykiem powodziowym, który jest obecnie wdrażany w Polsce i pozostałych krajach unijnych.

Materiał dokumentacyjny stanowiły również wyniki Wstępnej oceny ryzyka powodziowego (WORP), opracowanej dla województwa wielkopolskiego oraz mapy: obszarów narażonych na niebezpieczeństwo powodzi (ONNP), znaczących powodzi historycznych oraz obszarów, na których wystąpienie powodzi jest prawdopodobne (KZGW 2015). Szczegółowy zasięg stref zagrożonych zalaniem, ze wskazaniem głębokości zalewu, oraz potencjalne, negatywne skutki związane z powodzią, która może wystąpić zgodnie z jednym ze scenariuszy prawdopodobieństwa, prezentują odpowiednio mapy zagrożenia powodziowego i ryzyka powodziowego, opracowane w systemie ISOK i udostępniane na Hydroportalu Krajowego Zarządu Gospodarki Wodnej (Hydroportal KZGW).

W zakresie analizy stopnia realizacji celów środowiskowych, tzn. osiągnięcia dobrego stanu lub potencjału ekologicznego wód do 2015 r. lub wystąpienia ryzyka nieosiągnięcia wskazanych celów (Dyrektywa 2000/60/WE) wykorzystano dane pochodzące z opracowania Charakterystyki jednolitych części wód (Plan gospodarowania wodami na obszarze dorzecza Odry, M.P. 2011 r. nr 40 poz. 451) oraz z Aktualizacji Planu gospodarowania wodami na obszarze dorzecza Odry (2015-2021) (KZGW 2015). Dokument ten określa działania w zakresie usprawnienia procesu osiągania lub utrzymania dobrego stanu (lub potencjału) wód oraz związanych z nimi ekosystemów, a także uwzględnia zintegrowane podejście w zakresie zarządzania wodami.

\section{Obszar badań}

Obszar badań zlokalizowany jest w środkowej części Niziny Wielkopolskiej, pomiędzy mezoregionami: Pojezierzem Poznańskim, Pojezierzem Gnieźnieńskim, Wysoczyzną Kaliską i Wysoczyną Uniejowską (Kondracki 2002). Wytypowany do analizy środkowy odcinek doliny Warty obejmuje jej pradolinny fragment między miastami 
Konin i Śrem (Pradolina Warszawsko-Berlińska) oraz odcinek Poznańskiego Przełomu Warty między Śremem a Obornikami (ryc. 1). Łącznie analizie poddano odcinek biegu Warty o długości 201,1 km, uwzględniając lokalizację Konina (406,6 km biegu Warty) i Obornik (205,5 km biegu Warty). Każdy z wytypowanych segmentów doliny Warty, do połączenia których dochodzi w okolicach Śremu, cechuje się zróżnicowaną morfologią, użytkowaniem terenu oraz stopniem przekształcenia, a także specyfiką cech reżimu rzecznego. Szerokość pradoliny jest zmienna (15 km-20 km), a jej płaskie dno wypełnione jest torfowiskami. Odcinek przełomowy jest stosunkowo wąski (do kilku km) i wcięty względem terenów sąsiednich na głębokość do 15 m-20 m. Poszczególne odcinki biegu Warty różnią się również liczbą dopływów i charakterem zagospodarowania ich zlewni.

Stopień przekształcenia i zainwestowania doliny rzecznej jest najwyższy w miastach - w Poznaniu (metropolia Poznań) i Śremie oraz w rejonie miast Konin i Koło (zaliczanych do terenów eksploatacji węgla brunatnego oraz związanych z tym szkód górniczych). Wysokim wskaźnikiem zurbanizowania i zabudowy, powyżej 40\%-50\% cechuje się zlewnia bezpośrednia Warty w rejonie Poznania oraz jej dopływów, np. zlewnie Potoku Junikowskiego i Bogdanki, które położone są w granicach miasta. Rejestrowany wzrost antropopresji w dolinie Warty może prowadzić w przyszłości do nieodwracalnych zmian w strukturze bilansu wodnego (Graf 2012, 2014a) oraz przyczyniać się z jednej strony do wzrostu zagrożenia i ryzyka powodziowego, a z drugiej - do ograniczenia możliwości osiągnięcia dobrego stanu lub potencjału ekologicznego wód (Graf, Pyszny 2016).

$\mathrm{Na}$ Warcie i jej dopływach, które cechują się śnieżno-deszczowym ustrojem zasilania, powodzie występują w obu półroczach. W sezonie wiosennym są one wywoływane topnieniem śniegu wzmocnionym opadami deszczu (tzw. powodzie roztopowe). W sezonie letnim zaś powodzie są skutkiem gwałtownych opadów atmosferycznych (tzw. powodzie opadowo-nawalne). Spływ wód powodziowych w okresie zimowo-wiosennym może utrzymywać się do 2-3 miesięcy, a potęgują go zatory lodowe, które na Warcie rejestrowane są przede wszystkim w rejonie Śremu, gdzie następuje zmiana kierunku odwodnienia z równoleżnikowego na przełomowy (Graf 2015). W regionie wodnym Warty spływ wód powodziowych jest zazwyczaj długotrwały i mało gwałtowny, a dodatkowe utrudnienie w małych zlewniach stanowią zjawiska lodowe i zarastanie.

Dolina Warty, mimo silnego zainwestowania i zmian antropogenicznych, cechuje się również wysokim walorami przyrodniczymi i krajobrazowymi. Istotną jej cechą jest występowanie na rozpatrywanym odcinku zróżnicowanych form ochrony przyrody wydzielonych zgodnie z Ustawą z 16 kwietnia 2004 r. o ochronie przyrody (Ustawa o ochronie przyrody 2004) (por. tab. 1).

Na odcinku doliny Warty pomiędzy Koninem a Śremem (odcinek pradolinny) występują parki krajobrazowe oraz obszary Natura 2000 (źródło: Generalna Dyrekcja 

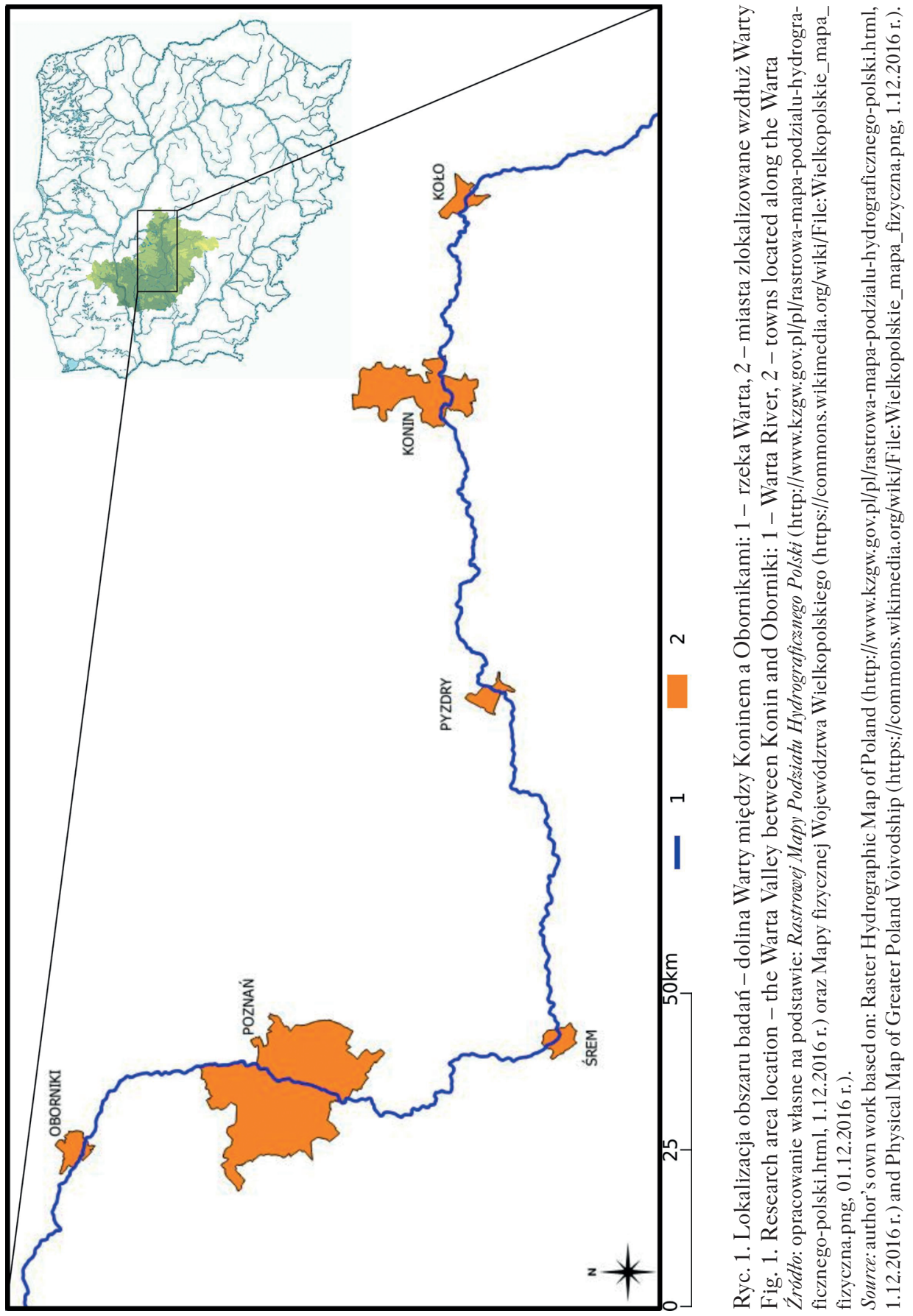
Tab. 1. Formy ochrony przyrody zlokalizowane w zasięgu doliny Warty na odcinku KoninOborniki

Table 1. Nature conservation forms located in the Warta Valley within the Konin-Oborniki stretch

\begin{tabular}{|c|c|c|}
\hline $\begin{array}{l}\text { Forma ochrony } \\
\text { Conservation form }\end{array}$ & $\begin{array}{l}\text { Dolina Warty na odcinku } \\
\text { Konin-Śrem } \\
\text { Warta Valley within the } \\
\text { Konin-Śrem stretch }\end{array}$ & $\begin{array}{l}\text { Dolina Warty na odcinku Śrem-Oborniki } \\
\text { Warta Valley within the Śrem-Oborniki stretch }\end{array}$ \\
\hline Park narodowy & brak & Wielkopolski Park Narodowy WPN (nr $\left.1^{\star \star \star *}\right)$ \\
\hline Rezerwat & brak & Krajkowo REZ738, Dołęga REZ 654 \\
\hline Park Krajobrazowy & $\begin{array}{l}\text { Żerkowsko-Czeszewski Park } \\
\text { Krajobrazowy PK81 (nr } 4^{\star * *} \text { ), } \\
\text { Nadwarciański Park Krajobrazowy } \\
\text { PK83 (nr 6) }\end{array}$ & $\begin{array}{l}\text { Park Krajobrazowy Puszcza Zielonka PK86 } \\
\text { (nr 2), Rogaliński Park Krajobrazowy PK68 } \\
\text { (nr 3), Park Krajobrazowy Promno PK84, } \\
\text { Lednicki Park Krajobrazowy PK82, } \\
\text { Park Krajobrazowy im. gen. Dezyderego } \\
\text { Chłapowskiego PK10 (nr 5) }\end{array}$ \\
\hline $\begin{array}{l}\text { Obszar Natura 2000: } \\
\text { A. Specjalny obszar ochrony } \\
\text { siedlisk (SOOS)-wydzielony } \\
\text { na podstawie Dyrektywy } \\
\text { Siedliskowej }^{*} \\
\text { B. Obszar specjalnej ochrony } \\
\text { ptaków (OSO -wydzielony na } \\
\text { podstawie Dyrektywy Ptasiej }{ }^{\star *}\end{array}$ & $\begin{array}{l}\text { A. Rogalińska Dolina Warty } \\
\text { PLH300012, Lasy Żerkowsko- } \\
\text {-Czeszewskie PLH300053, Ostoja } \\
\text { Nadwarciańska PLH300009 } \\
\text { B. Ostoja Rogalińska PLB300017, } \\
\text { Dolina Środkowej Warty PLB300002 }\end{array}$ & $\begin{array}{l}\text { A. Ostoja Wielkopolska PLH300010, } \\
\text { Rogalińska Dolina Warty PLH300012, } \\
\text { Biedrusko PLH300001, Uroczyska Puszczy } \\
\text { Zielonki PLH300058, Ostoja koło Promna } \\
\text { PLH300030, Dolina Cybiny PLH300038 } \\
\text { B. Ostoja Rogalińska PLB300017, Dolina } \\
\text { Samicy PLB300013 }\end{array}$ \\
\hline
\end{tabular}

Objaśnienia: * Dyrektywa Siedliskowa (dyrektywa habitatowa) - Dyrektywa 92/43/EWG w sprawie ochrony siedlisk przyrodniczych oraz dzikiej fauny i flory, stanowiąca podstawę europejskiego systemu ochrony przyrody Natura 2000.

** Dyrektywa Ptasia - dyrektywa 2009/147/WE z 30 listopada 2009 r. w sprawie ochrony dzikiego ptactwa, stanowiąca podstawę europejskiego systemu ochrony przyrody Natura 2000

****Numer zgodny z numeracją na ryc. 2

Explanations: * The Habitats Directive - Directive 92/43/EEG on the conservation of natural habitats and of wild fauna and flora, which is a basis of the European nature protection system Natura 2000

** The Birds Directive - Directive 2009/147/EC of 30 November 2009 on the conservation of wild birds, which is a basis of the European nature protection system Natura 2000

*** The number as per the numbering in Fig. 2

Ochrony Środowiska), natomiast pomiędzy Śremem i Obornikami, oprócz wymienionych form, znajduje się Wielkopolski Park Narodowy oraz kilka rezerwatów przyrody (ryc. 2).

W odniesieniu do Warty system obszarowych form ochrony przyrody obejmuje prawie całą dolinę rzeki z wyłączeniem jej fragmentów znajdujących się przede 

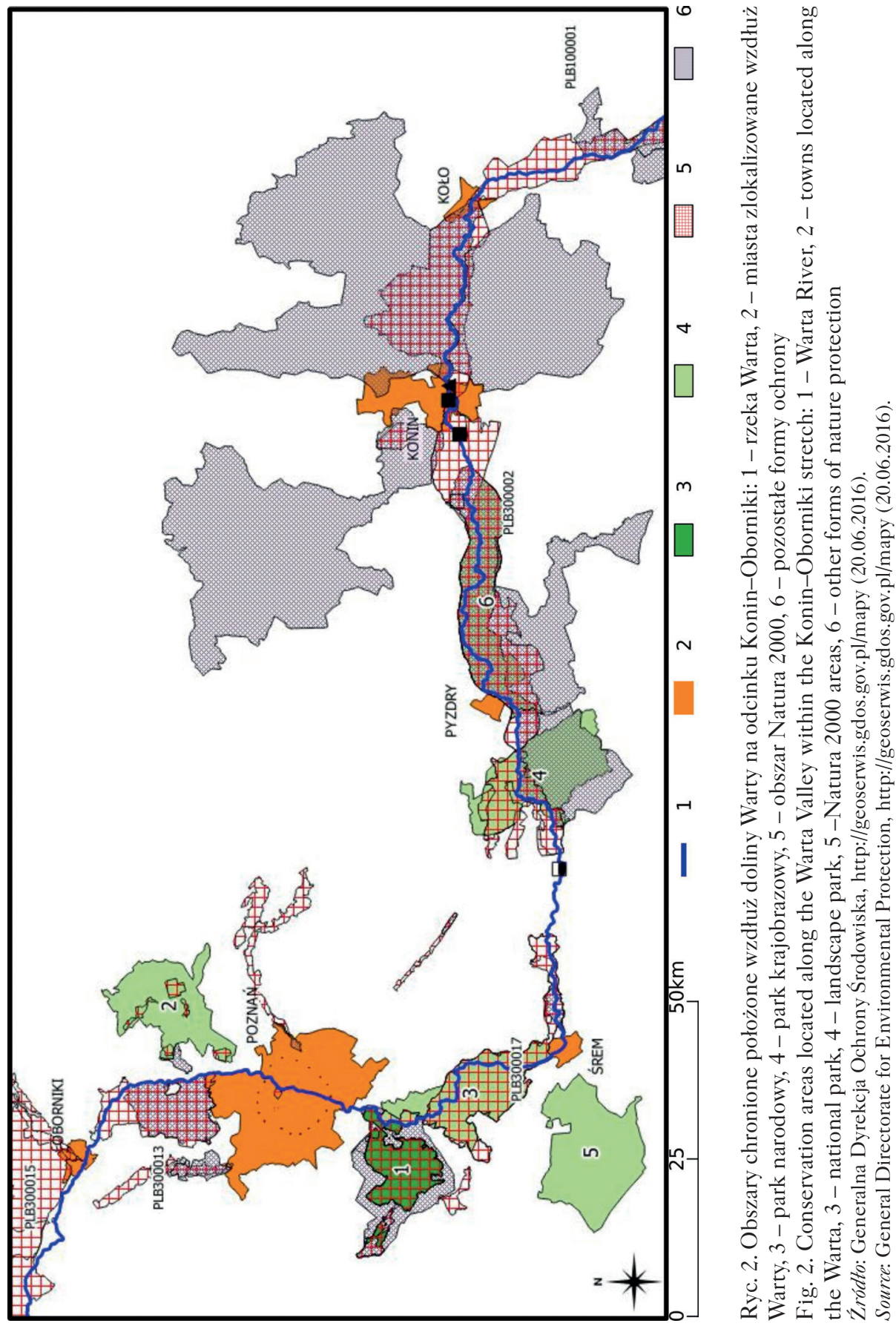
wszystkim na terenie miasta Poznania. Szczególnie istotne znaczenie mają obszary Natura 2000 utworzone dla ochrony gatunków ptaków lub siedlisk, dla których utrzymanie lub poprawa stanu wód jest ważnym czynnikiem w ich ochronie.

\section{Wyniki}

Realizacja celów wodnogospodarczych, zintegrowanych z celami środowiskowymi przyczynia się do występowania zjawisk i konfliktów o dużym nasileniu. Przeprowadzona analiza wykazała, że na rozpatrywanym odcinku doliny Warty istnieje wysokie ryzyko powodziowe oraz ryzyko nieosiągnięcia celów środowiskowych w jednolitych częściach wód powierzchniowych, do którego przyczynia się wzrost presji antropogenicznej.

Analizowany odcinek doliny Warty jest w różnym stopniu narażony na występowanie powodzi, co potwierdziła analiza map obszarów narażonych na niebezpieczeństwo wystąpienia powodzi (ONNP) oraz map powodzi historycznych i prawdopodobnych, opracowanych dla województwa wielkopolskiego w ramach Wstępnej oceny ryzyka powodziowego (ryc. 3). W dolinie Warty większym stopniem zagrożenia powodziowego cechuje się odcinek pradolinny od Konina do Śremu, gdzie dodatkowo potęguje je duży dopływ - Prosna (ryc. 3A). Rozpatrywane odcinki doliny Warty zaklasyfikowane zostały do obszarów ONNP, na których stwierdzono istnienie znacznego ryzyka powodziowego. Znaczące powodzie historyczne, tzn. powodzie, które wystąpiły w przeszłości i miały negatywne skutki dla zdrowia ludzkiego, środowiska, dziedzictwa kulturowego oraz działalności gospodarczej, dotyczą natomiast głównie Warty oraz jej dopływów: Prosny i Wrześnicy, w odcinku pradolinnym oraz Kanału Mosińskiego w odcinku przełomowym (ryc. 3B). Z kolei do rzek, na których wystąpienie powodzi jest prawdopodobne, zaliczono w omawianym rejonie, oprócz Warty, jej dopływy: Kiełbaskę, Prosnę, Moskawę, Bawół, Wrześnicę (odcinek pradolinny) oraz Kanał Mosiński, Wirynkę, Kopel, Cybinę, Główną i rzekę Wełnę w odcinku przełomowym Warty (ryc. 3C).

Analiza stopnia ryzyka powodziowego na Warcie i jej dopływach wykazała jego najwyższy poziom w Kaliszu nad Prosną (poza analizowanym obszarem), bardzo wysoki w rejonie Konina-Morzysława oraz wysoki poziom m.in. w gminach: Golina, Poznań, Luboń i Oborniki, umiarkowany zaś w gminach: Komorniki, Mosina, Pobiedziska, Puszczykowo i Śrem (ryc. 1). Wzrost ryzyka powodziowego wywołuje m.in. intensywna zabudowa obszarów zagrożonych powodzią oraz zbyt intensywna zabudowa obszarów chronionych obwałowaniami, szczególnie w miastach: Poznań, Oborniki, Luboń, Śrem, Pyzdry oraz Konin. Problemem jest również postępująca zabudowa i zagospodarowanie terenów polderów (np. poldery Golina, Krzykosy, Nizina Konińska). Zagrożenie powodziowe zwiększa również nieodpowiedni, wymagający modernizacji stan techniczny wałów przeciwpowodziowych, m.in. wały rzeki Warty na terenie gmin Śrem i Krzykosy oraz miasta Poznań (PZRP dla RWW 2015). 


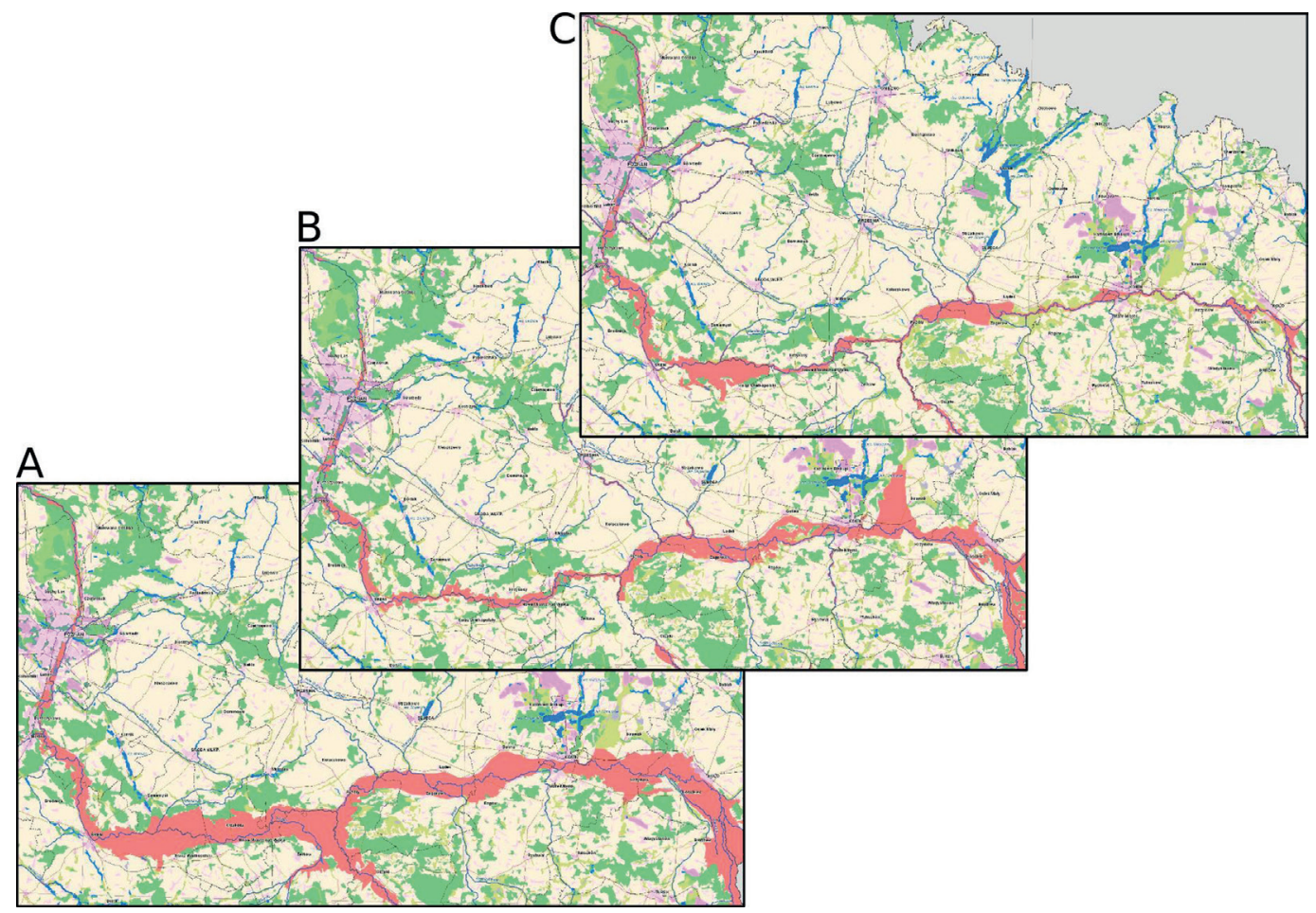

Ryc. 3. Wstępna ocena ryzyka powodziowego dla obszaru doliny Warty między Koninem i Obornikami: A - obszary narażone na niebezpieczeństwo powodzi (ONNP), B - znaczące powodzie historyczne, $\mathrm{C}$ - obszary, na których wystąpienie powodzi jest prawdopodobne Fig. 3. Preliminary Flood Risk Assessment for the Warta Valley between Konin and Oborniki: A - areas threatened by flood hazard (ONNP), B - major historic floods, $\mathrm{C}$ - areas where flood occurrence is probable

Źródto: Wstępna ocena ryzyka powodziowego (WORP), KZGW, http://www.kzgw.gov.pl/pl/wstepna-ocena-ryzyka- powodziowego.html (20.06.2016).

Source: Preliminary Flood Risk Assessment (ONNP), KZGW, http://www.kzgw.gov.pl/pl/wstepna-ocena-ryzyka-powodziowego.html (20.06.2016). 
Zdolność retencyjna doliny Warty nie jest wystarczająca do skutecznego ograniczenia zagrożenia powodziowego. Retencja w zlewni utrzymuje się na poziomie $2 \%-4 \%$ odpływu rzecznego przy konieczności utrzymania jej na poziomie ok. 10\%-12\%. W przypadku terenów silnie zurbanizowanych (Poznań, Luboń i Konin) dodatkowym czynnikiem zwiększającym zagrożenie związane z zalaniem lub podtopieniem terenu są intensywne, krótkotrwałe opady deszczu, najczęściej typu burzowego, których skutkiem jest przyspieszenie spływu powierzchniowego z terenów miejskich przy niewydolnych systemach kanalizacji oraz brak właściwego odpływu wód z tzw. zawala.

Zgodnie z Planem zarządzania ryzykiem powodziowym opracowanym dla regionu wodnego Warty (PZRP dla RWW 2015) na analizowanym odcinku doliny Warty, adekwatnie do stopnia zagrożenia i ryzyka powodziowego, zaplanowano realizację różnego rodzaju działań: ochronnych, przygotowawczych i zapobiegawczych. Inwestycje techniczne, związane z ograniczaniem zagrożenia powodziowego i minimalizacją istniejącego ryzyka powodziowego, mogą mieć negatywny wpływ na realizację celów środowiskowych. Na odcinku doliny Warty pomiędzy Koninem a Obornikami wytypowano do realizacji w okresie 2016-2021 20 działań technicznych (tab. 2), których lokalizację przedstawiono na mapie, przypisując każdemu działaniu identyfikator (ID) zgodny z numerem inwestycji określonych w Planie zarządzania ryzykiem powodziowym (ryc. 4). Tylko w jednym przypadku jako cel wskazano zapotrzebowanie rolnictwa z zakresu działań melioracyjnych, a w kilku przypadkach cel określono jako inny niż wymienione, np. transport, żegluga.

Wśród wytypowanych inwestycji znajdują się: budowa, przebudowa lub remont wałów przeciwpowodziowych oraz prace w korycie Warty związane z udrożnieniem i regulacją rzeki w celu poprawy parametrów drogi wodnej oraz remont ostróg. Do pozostałych inwestycji zaliczono budowę lub modernizację budowli piętrzących (budowle regulacyjne) oraz pompowni (tab. 2, ryc. 4). Na liście strategicznych inwestycji technicznych, czyli działań o charakterze priorytetowym, przewidzianych do realizacji na omawianym odcinku doliny Warty w pierwszej kolejności znajdują się dwa przedsięwzięcia przypisane do tzw. hot-spotów: Golina i Poznań-Luboń. Hotspoty reprezentują obszary problemowe o zidentyfikowanym, znaczącym ryzyku powodziowym (PZRP dla RWW 2015). W regionie wodnym Warty wyróżniono w sumie 11 hotspotów, które odnoszą się do większych miast zlokalizowanych nad Wartą.

Budowa polderu Golina jest planowana do realizacji w ramach rewitalizacji tzw. Doliny Konińsko-Pyzderskiej, która przed jej obwałowaniem stanowiła duży, naturalny zbiornik retencyjny o pojemności dochodzącej do $360 \mathrm{mln} \mathrm{m}^{3}$ (PZRP dla RWW 2015). W wyniku obwałowania doliny pojemność potencjalnych obszarów przeznaczonych na poldery obniżyła się o ok. $45 \%$. W planie przewiduje się przekształcenie gospodarcze obszaru Golina w polder z przeznaczeniem pod zalew 

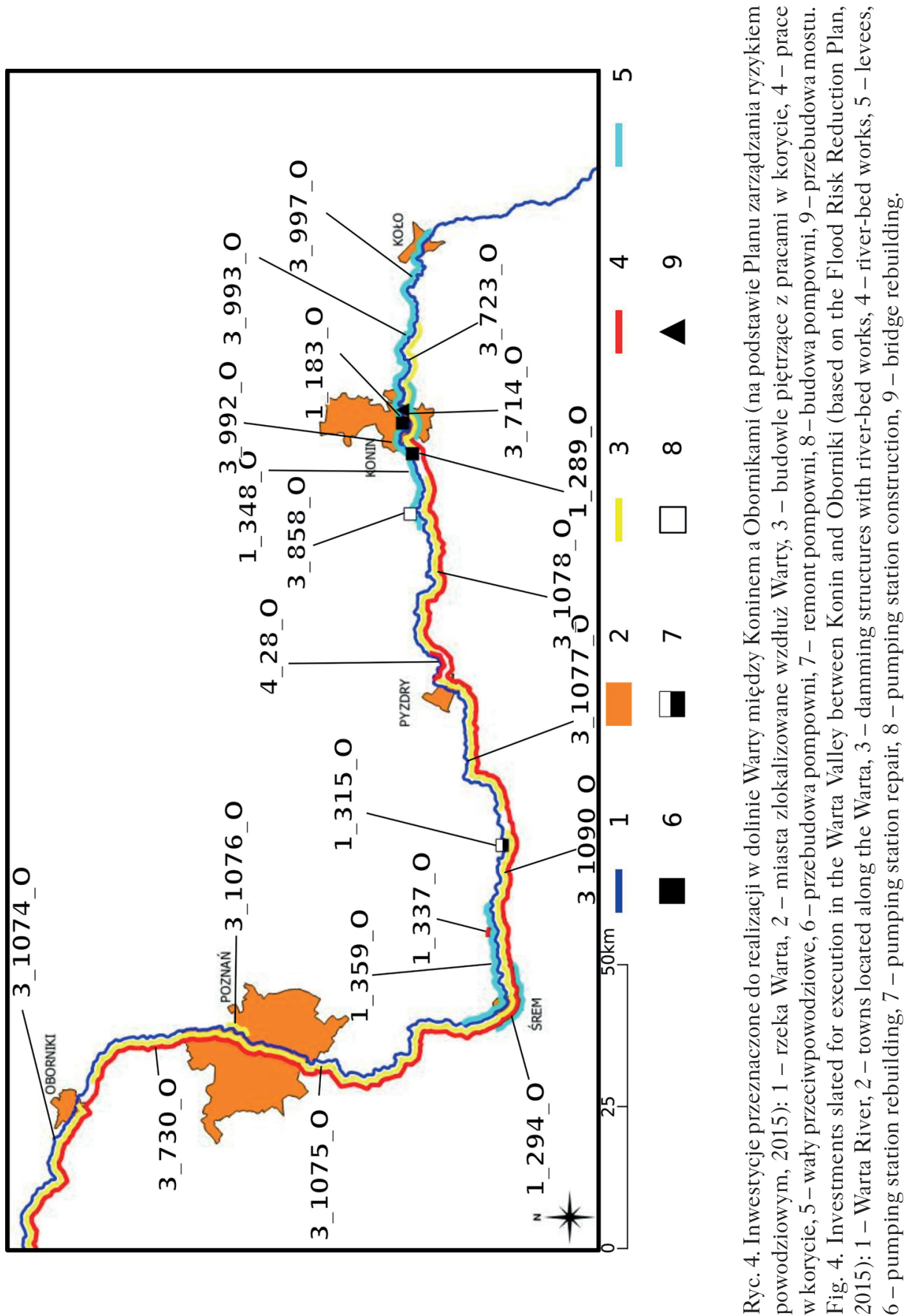
Tab. 2. Inwestycje przewidziane do realizacji w dolinie Warty na odcinku Konin-Oborniki w okresie 2016-2021 w zakresie ograniczenia zagrożenia powodziowego

Table 2. Investments slated for execution in the Warta Valley within the Konin-Oborniki stretch in the period 2016-2021 aimed at flood hazard reduction

\begin{tabular}{|c|c|c|c|c|c|c|}
\hline $\begin{array}{l}\text { Nazwa/rodzaj inwestycji } \\
\text { Investment name/type }\end{array}$ & $I D^{\star}$ & $\begin{array}{l}\text { Cel inwestycji } \\
\text { Investment } \\
\text { objective }\end{array}$ & $\begin{array}{c}\text { Data } \\
\text { zakończenia } \\
\text { Completion } \\
\text { date }\end{array}$ & $\begin{array}{l}\text { Nr jcwp** } \\
\text { Surface } \\
\text { water } \\
\text { body } \\
\text { no. }{ }^{\star \star}\end{array}$ & $\begin{array}{l}\text { Kod obszaru } \\
\text { Natura } 2000^{*} \\
\text { Natura } 2000 \\
\text { area code }\end{array}$ & $\begin{array}{l}\text { Wynik oceny } \\
\text { wpływu } \\
\text { Impact } \\
\text { assessment } \\
\text { result }\end{array}$ \\
\hline $\begin{array}{l}\text { Przepompownia Nizina } \\
\text { Konińska - modernizacja }\end{array}$ & 1_283_0 & $\begin{array}{l}\text { ograniczenie } \\
\text { zagrożenia } \\
\text { powodziowego }\end{array}$ & 2015 & 493 & PLB300002 & brak oceny \\
\hline $\begin{array}{l}\text { Przepompownia } \\
\text { Komorze - modernizacja }\end{array}$ & 1_315_0 & $\begin{array}{l}\text { ograniczenie } \\
\text { zagrożenia } \\
\text { powodziowego }\end{array}$ & 2018 & 495 & $\begin{array}{l}\text { PLH300009 } \\
\text { PLB300002 }\end{array}$ & możliwy \\
\hline $\begin{array}{l}\text { Regulacja rzeki Warty } \\
\text { nieżeglownej w km } \\
407+000-432+200- \\
\text { budowle regulacyjne }\end{array}$ & 3_723_0 & $\begin{array}{l}\text { ograniczenie } \\
\text { zagrożenia } \\
\text { powodziowego }\end{array}$ & 12.2016 & 492 & PLB300002 & możliwy \\
\hline $\begin{array}{l}\text { Remont wału przeciwpo- } \\
\text { wodziowego rzeki Warty } \\
\text { - Polder Nizina Konińska }\end{array}$ & 3_992_0 & $\begin{array}{l}\text { ochrona przed } \\
\text { powodzią }\end{array}$ & 2016 & 492,493 & PLB300002 & możliwy \\
\hline $\begin{array}{l}\text { Remont wału } \\
\text { przeciwpowodziowego } \\
\text { rzeki Warty - Polder } \\
\text { Gozdów }\end{array}$ & 3_997_0 & $\begin{array}{l}\text { ochrona przed } \\
\text { powodzią }\end{array}$ & 2016 & 492 & PLB300002 & możliwy \\
\hline $\begin{array}{l}\text { Remont ostróg rzeki } \\
\text { Warty w miejscowości } \\
\text { Białobrzeg }\end{array}$ & 4_28_0 & $\begin{array}{l}\text { ograniczenie } \\
\text { zagrożenia } \\
\text { powodziowego }\end{array}$ & 12.2015 & 494 & $\begin{array}{l}\text { PLB300002 } \\
\text { PLH300009 }\end{array}$ & możliwy \\
\hline $\begin{array}{l}\text { Modernizacja } \\
\text { lewobrzeżnego wału } \\
\text { przeciwpowodziowego na } \\
\text { Polderze Rumin wraz z } \\
\text { przepompownią Rumin }\end{array}$ & 1_289_0 & $\begin{array}{l}\text { ochrona przed } \\
\text { powodzią, } \\
\text { rolnictwo/ } \\
\text { melioracja }\end{array}$ & 2021 & 494 & $\begin{array}{c}\text { PLH- } \\
\text { 300009PLB300002 }\end{array}$ & możliwy \\
\hline $\begin{array}{l}\text { Modernizacja wałów } \\
\text { Wójtostwo-Łężek } \\
\text { i m. Śrem }\end{array}$ & 1_294_0 & $\begin{array}{l}\text { ochrona przed } \\
\text { powodzią }\end{array}$ & 2021 & 497,498 & $\begin{array}{l}\text { PLB300017 } \\
\text { PLH300012 }\end{array}$ & brak oceny \\
\hline $\begin{array}{l}\text { Poprawa bezpieczeństwa } \\
\text { przeciwpowodziowego } \\
\text { w dolinie rzeki Warty - } \\
\text { budowa polderu Golina }\end{array}$ & 1_348_0 & $\begin{array}{l}\text { ochrona przed } \\
\text { powodzią }\end{array}$ & 12.2020 & 493,494 & $\begin{array}{l}\text { PLB300002 } \\
\text { PLH300009 }\end{array}$ & możliwy \\
\hline $\begin{array}{l}\text { Odbudowa wałów prawo- } \\
\text { stronnych } \\
\text { i lewostronnych } \\
\text { rzeki Warty }\end{array}$ & 1_359_0 & $\begin{array}{l}\text { ochrona przed } \\
\text { powodzią }\end{array}$ & 2021 & 497,498 & $\begin{array}{l}\text { PLB300017 } \\
\text { PLH300012 }\end{array}$ & brak oceny \\
\hline $\begin{array}{l}\text { Regulacja rzeki Warty } \\
\text { w km } 30+000-212+000- \\
\text { budowle regulacyjne }\end{array}$ & 3_1074_0 & $\begin{array}{l}\text { ograniczenie } \\
\text { zagrożenia } \\
\text { powodziowego }\end{array}$ & 12.2020 & $\begin{array}{l}501,502 \\
\quad 503\end{array}$ & $\begin{array}{l}\text { PLC080001 } \\
\text { PLH080006 } \\
\text { PLB080002 } \\
\text { PLB300015 } \\
\text { PLH300001 } \\
\text { PLH300003 }\end{array}$ & $\begin{array}{l}\text { zniszczenie } \\
\text { siedlisk } \\
\text { przyrodniczych } \\
\text { i gatunków na } \\
\text { trasie odbudo- } \\
\text { wy wału }\end{array}$ \\
\hline
\end{tabular}




\begin{tabular}{|c|c|c|c|c|c|c|}
\hline $\begin{array}{l}\text { Nazwa/rodzaj inwestycji } \\
\text { Investment name/type }\end{array}$ & $I D^{*}$ & $\begin{array}{l}\text { Cel inwestycji } \\
\text { Investment } \\
\text { objective }\end{array}$ & $\begin{array}{l}\text { Data } \\
\text { zakończenia } \\
\text { Completion } \\
\text { date }\end{array}$ & $\begin{array}{c}\text { Nr jcwp** } \\
\text { Surface } \\
\text { water } \\
\text { body } \\
\text { no. }{ }^{\star *}\end{array}$ & $\begin{array}{l}\text { Kod obszaru } \\
\text { Natura } 2000^{* *} \\
\text { Natura } 2000 \\
\text { area code }\end{array}$ & $\begin{array}{l}\text { Wynik oceny } \\
\text { wpływu } \\
\text { Impact } \\
\text { assessment } \\
\text { result }\end{array}$ \\
\hline $\begin{array}{l}\text { Regulacja rzeki Warty w } \\
\text { km } 217+000-330+600- \\
\text { budowle regulacyjne }\end{array}$ & 3_1075_0 & $\begin{array}{l}\text { ograniczenie } \\
\text { zagrożenia } \\
\text { powodziowego }\end{array}$ & 12.2021 & $\begin{array}{l}496,497 \\
498,499 \\
500,501\end{array}$ & $\begin{array}{l}\text { PLH300001 } \\
\text { PLB300017 } \\
\text { PLH300005 } \\
\text { PLH300012 } \\
\text { PK81 } \\
\text { PLH300053 } \\
\text { PLB300002 }\end{array}$ & możliwy \\
\hline $\begin{array}{l}\text { Regulacja rzeki Warty } \\
\text { w km } 243+500-246+000 \text { - } \\
\text { budowle regulacyjne }\end{array}$ & 3_1076_0 & $\begin{array}{l}\text { ograniczenie } \\
\text { zagrożenia } \\
\text { powodziowego }\end{array}$ & 12.2017 & 499 & nie dotyczy & możliwy \\
\hline $\begin{array}{l}\text { Regulacja rzeki Warty } \\
\text { w km } 334+300-362+600 \\
\text { budowle regulacyjne }\end{array}$ & 3_1077_0 & $\begin{array}{l}\text { ograniczenie } \\
\text { zagrożenia } \\
\text { powodziowego }\end{array}$ & 12.2018 & $\begin{array}{l}494,495 \\
496\end{array}$ & $\begin{array}{l}\text { PLB300002 } \\
\text { PLH300053 } \\
\text { PLH } 300009\end{array}$ & nie dotyczy \\
\hline $\begin{array}{l}\text { Regulacja rzeki Warty } \\
\text { w km } 367+500-402+900- \\
\text { budowle regulacyjne }\end{array}$ & 3_1078_0 & $\begin{array}{l}\text { ograniczenie } \\
\text { zagrożenia } \\
\text { powodziowego }\end{array}$ & 12.2018 & 493,494 & $\begin{array}{l}\text { PLB300002 } \\
\text { PLH300009 }\end{array}$ & możliwy \\
\hline $\begin{array}{l}\text { Udrożnienie i regulacja } \\
\text { rzeki Warty na odcinku od } \\
\text { km 252+000 } \\
\text { (m. Luboń) do km } \\
406+600 \text { (m. Konin) } \\
\text { W celu poprawy } \\
\text { parametrów drogi wodnej }\end{array}$ & 3_1090_0 & $\begin{array}{l}\text { ograniczenie } \\
\text { zagrożenia } \\
\text { powodziowego }\end{array}$ & 11.2021 & $\begin{array}{l}492,493 \\
494,495 \\
496,497 \\
498,499\end{array}$ & $\begin{array}{l}\text { PLB300017 } \\
\text { PLB300002 } \\
\text { PLH300012 } \\
\text { PLH300053 } \\
\text { PLH300005 } \\
\text { PLH300009 }\end{array}$ & możliwy \\
\hline $\begin{array}{l}\text { Przebudowa wału } \\
\text { przeciwpowodziowego } \\
\text { rzeki Warty - wał opaskowy }\end{array}$ & 3_714_0 & $\begin{array}{l}\text { ochrona przed } \\
\text { powodzią }\end{array}$ & 2021 & 492,493 & $\begin{array}{l}\text { PLH300009 } \\
\text { PLB300002 }\end{array}$ & możliwy \\
\hline $\begin{array}{l}\text { Udrożnienie i regulacja } \\
\text { rzeki Warty na odcinku od } \\
\text { km } 68+200 \text { (m. Santok) } \\
\text { do km 252+000 } \\
\text { (m. Luboń) w celu } \\
\text { poprawy parametrów } \\
\text { drogi wodnej }\end{array}$ & 3_730_0 & inny & 11.2021 & $\begin{array}{l}499,500 \\
501,502 \\
503\end{array}$ & $\begin{array}{l}\text { PLB080002 } \\
\text { PLB300015 } \\
\text { PLH080006 } \\
\text { PLH300032 }\end{array}$ & możliwy \\
\hline $\begin{array}{l}\text { Odprowadzenie wody } \\
\text { z Polderu Barłogi do rzeki } \\
\text { Warty }\end{array}$ & 3_858_0 & $\begin{array}{l}\text { ograniczenie } \\
\text { zagrożenia } \\
\text { powodziowego }\end{array}$ & 2016 & 492 & $\begin{array}{l}\text { PLH300009, } \\
\text { PLB300002 }\end{array}$ & możliwy \\
\hline $\begin{array}{l}\text { Remont wału przeciwpo- } \\
\text { wodziowego rzeki Warty- } \\
\text {-Polder Krzymów }\end{array}$ & 3_993_0 & $\begin{array}{l}\text { ochrona przed } \\
\text { powodzią }\end{array}$ & 2016 & 492,493 & PLB300002 & możliwy \\
\hline
\end{tabular}

Objaśnienia: * ID - identyfikator inwestycji zgodny z ID zamieszczonym na ryc. 4; ** Numer jcwp zgodny z numeracją w tab. 3 (wg RZGW w Poznaniu); **** Kod obszaru Natura 2000 zgodny z kodem zamieszczonym na ryc. 2

Explanations: * ID - investment identifier corresponding to the ID in Fig. 4; ** The surface water body number corresponding to the numbering in Table 3 (after the Poznań Regional Water Management Authority; *** Natura 2000 area code corresponding to the code in Fig. 2

Źródto: opracowanie własne na podstawie: PZRP, RZGW Poznań.

Source: author's own work on the basis of the Flood Risk Reduction Plans for the Warta Water Region Poznań Regional Water Management Authority. 
wodami powodziowymi. Obszarem problemowym o zidentyfikowanym znaczącym ryzyku powodziowym jest również tzw. hot-spot Poznań-Luboń cechujący się zbyt intensywną zabudową obszarów zagrożonych powodzią (Luboń) i obszarów chronionych obwałowaniami (Poznań). Realizacja zaplanowanych inwestycji w dolinie Warty na odcinku Konin-Oborniki jest niezbędna - szczególnie w strefie omawianych hotspotów - ze względu na charakter zagrożenia związany z bardzo wysokim i wysokim poziomem ryzyka powodziowego (np. zagrożenie w rejonach silnie zurbanizowanej części miast) oraz koniecznością poprawy bezpieczeństwa przeciwpowodziowego. Potwierdzono, że zaniechanie prac mających na celu przywrócenie parametrów hydraulicznych koryta rzeki Warty w wymienionych strefach może zwiększać zagrożenie powodziowe (PZRP dla RWW 2015).

Z punktu widzenia realizacji założeń Ramowej dyrektywy wodnej (Dyrektywa 2000/60/WE) w dolinie Warty między Koninem a Obornikami, podobnie jak w całym regionie wodnym Warty, zidentyfikowane zostały istotne problemy dotyczące ryzyka nieosiągnięcia celów środowiskowych do 2015 r. w zakresie dobrego stanu lub potencjału ekologicznego wód. Na analizowanym odcinku doliny Warty wyróżniono 12 jednolitych części wód powierzchniowych (jcwp) (ryc. 5), wśród których wszystkie mają status silnie zmienionych wskutek działalności gospodarczej człowieka (tab. 3).

W zakresie oceny potencjału ekologicznego wód wydzielone jednolite części wód powierzchniowych osiągnęły zarówno stan umiarkowany (2 jcwp), słaby (4 jcwp), jak i zły (6 jcwp). Wszystkie jcwp znajdują się w grupie ryzyka nieosiągnięcia celów środowiskowych RDW, do którego przyczyniają się zmiany antropogeniczne zachodzące na analizowanym odcinku rzeki Warty, m.in.: wysoki stopień zurbanizowania, odwadnianie odkrywkowej kopalni węgla brunatnego, silne zmiany morfologiczne w korycie rzeki (zabudowa podłużna, regulacje) oraz zanieczyszczenia odprowadzane do wód z terenów użytkowanych rolniczo (tab. 3).

\section{Dyskusja}

System zintegrowanego zarządzania zasobami wodnymi, zgodnie z założeniami Ramowej dyrektywy wodnej (Dyrektywa 2000/60/WE), zakłada spójność w zakresie realizacji celów środowiskowych związanych przede wszystkim z osiągnięciem i zachowaniem dobrego stanu lub potencjału ekologicznego wód i ekosystemów zależnych od wody oraz poprawę i racjonalizację procesów zarządzania, w tym zarządzania ryzykiem powodziowym (Krauze, Wagner 2014; Kowalczak 2015; Mrozik i in. 2015; Graf, Pyszny 2016). Polityka wodna prowadzona obecnie przez kraje unijne wymaga integracji wszystkich celów oraz eliminacji negatywnych skutków działań wpływających na przebieg i wynik pozostałych, co nie zawsze jest możliwe do zrealizowania (Nachlik 2006). 

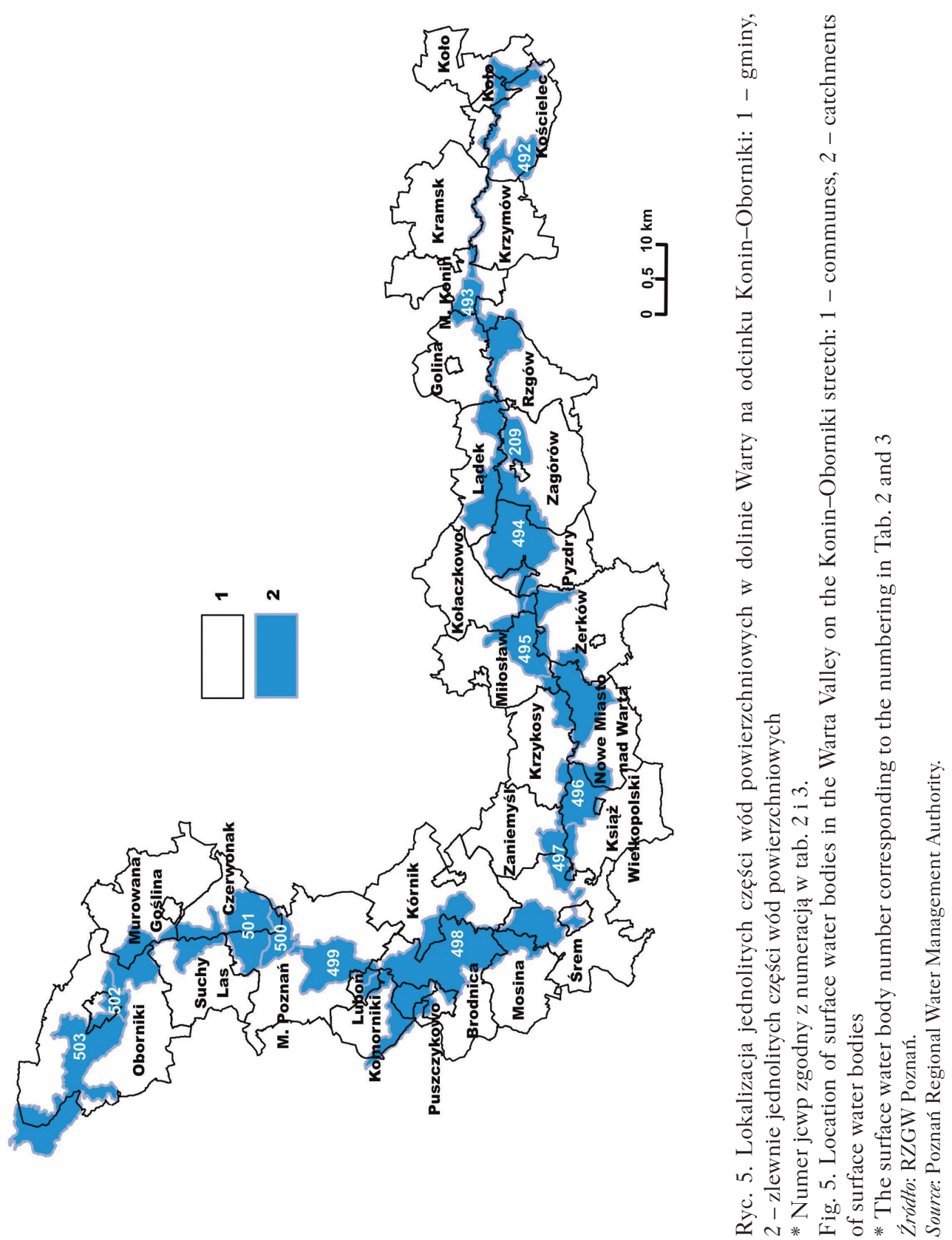
Tab. 3. Status, stan i zagrożenie jednolitych części wód powierzchniowych zlokalizowanych w zasięgu doliny Warty na odcinku Koło-Oborniki

Table 3. Status, condition and threat level of surface water bodies located in the Warta Valley within the Konin-Oborniki stretch

\begin{tabular}{|c|c|c|c|c|c|}
\hline \multirow[t]{2}{*}{$\begin{array}{l}\text { Nr jcwp* } \\
\text { Surface } \\
\text { water } \\
\text { body } \\
\text { number* }\end{array}$} & \multirow[t]{2}{*}{$\begin{array}{l}\text { Nazwa zlewni - kod } \\
\text { Catchment } \\
\text { name-code }\end{array}$} & \multirow[t]{2}{*}{$\begin{array}{l}\text { Status } \\
\text { jcwp } \\
\text { Surface } \\
\text { water body } \\
\text { status }\end{array}$} & \multicolumn{2}{|c|}{$\begin{array}{l}\text { Ocena stanu (potencjału)/ } \\
\text { ryzyka nieosiągnięcia celów } \\
\text { środowiskowych } \\
\text { Assessment of the potential } \\
\text { of the risk of failure to achieve } \\
\text { environmental objectives }\end{array}$} & \multirow[t]{2}{*}{$\begin{array}{l}\text { Czynniki i działania zagrażające } \\
\text { Hazardous factors and activities }\end{array}$} \\
\hline & & & $2011^{\star *}$ & $2014^{\star \star \star}$ & \\
\hline 492 & $\begin{array}{l}\text { Warta od Teleszyny } \\
\text { do Topca. Odcinek } \\
\text { Koło-Konin }\end{array}$ & $\begin{array}{l}\text { silnie } \\
\text { zmieniona }\end{array}$ & $\begin{array}{l}\text { umiarkowa- } \\
\text { ny/ } \\
\text { zagrożona }\end{array}$ & zagrożona & $\begin{array}{l}\text { silne zmiany morfologiczne, } 100 \% \\
\text { długości rzeki objęte zabudową podłużną, } \\
\text { odwodnienia odkrywkowej kopalni węgla } \\
\text { brunatnego }\end{array}$ \\
\hline 493 & $\begin{array}{l}\text { Warta od Topca } \\
\text { do Powy. Odcinek } \\
\text { Konin-Golina }\end{array}$ & $\begin{array}{l}\text { silnie } \\
\text { zmieniona }\end{array}$ & $\begin{array}{l}\text { umiarkowa- } \\
\text { ny/ } \\
\text { zagrożona }\end{array}$ & zagrożona & $\begin{array}{l}\text { silne zmiany morfologiczne, } 100 \% \\
\text { długości rzeki objęte zabudową podłużną, } \\
\text { obszar silnie zurbanizowany poniżej } 50 \% \\
\text { mieszkańców podłączonych do kanalizacji } \\
\text { odwodnienia odkrywkowej kopalni węgla } \\
\text { brunatnego }\end{array}$ \\
\hline 494 & $\begin{array}{l}\text { Warta od Powy do } \\
\text { Prosny. Odcinek } \\
\text { Golina-Lądek- } \\
\text { Pyzdry }\end{array}$ & $\begin{array}{l}\text { silnie } \\
\text { zmieniona }\end{array}$ & $\begin{array}{l}\text { słaby/ } \\
\text { zagrożona }\end{array}$ & niezagrożona & $\begin{array}{l}\text { silne zmiany morfologiczne, } 100 \% \\
\text { długości rzeki objęte zabudową podłużną, } \\
\text { odwodnienia odkrywkowej kopalni węgla } \\
\text { brunatnego }\end{array}$ \\
\hline 495 & $\begin{array}{l}\text { Warta od Prosny } \\
\text { do Lutyni. Odcinek } \\
\text { Pyzdry-Miłosław- } \\
\text { Orzechowo }\end{array}$ & $\begin{array}{l}\text { silnie } \\
\text { zmieniona }\end{array}$ & $\begin{array}{l}\text { zły/ } \\
\text { zagrożona }\end{array}$ & zagrożona & $\begin{array}{l}\text { silne zmiany morfologiczne, budowle } \\
\text { piętrzące i regulacyjne na rzece, } 70 \% \\
\text { zlewni użytkowane jest rolniczo }\end{array}$ \\
\hline 496 & $\begin{array}{l}\text { Warta od Lutyni do } \\
\text { Moskawy. Odcinek } \\
\text { Orzechowo-Nowe } \\
\text { Miasto nad Wartą }\end{array}$ & $\begin{array}{l}\text { silnie } \\
\text { zmieniona }\end{array}$ & $\begin{array}{l}\text { słaby/ } \\
\text { zagrożona }\end{array}$ & zagrożona & $\begin{array}{l}\text { silne zmiany morfologiczne, budow- } \\
\text { le piętrzące i regulacyjne na rzece, } \\
\text { obwałowania prawostronne rzeki Warty } \\
\text { (2010-2012) }\end{array}$ \\
\hline 497 & $\begin{array}{l}\text { Warta od Moskawy } \\
\text { do Pyszącej. } \\
\text { Odcinek } \\
\text { Nowe Miasto nad } \\
\text { Wartą-Śrem }\end{array}$ & $\begin{array}{l}\text { silnie } \\
\text { zmieniona }\end{array}$ & $\begin{array}{l}\text { zły/ } \\
\text { zagrożona }\end{array}$ & zagrożona & $\begin{array}{l}\text { ponad } 60 \% \text { powierzchni zlewni zajmują } \\
\text { tereny rolne, silne zmiany morfologiczne, } \\
\text { budowle piętrzące, regulacja }\end{array}$ \\
\hline 498 & $\begin{array}{l}\text { Warta od Pyszącej } \\
\text { do Kopli. Odcinek } \\
\text { Śrem-Luboń }\end{array}$ & $\begin{array}{l}\text { silnie } \\
\text { zmieniona }\end{array}$ & $\begin{array}{l}\text { zły/ } \\
\text { zagrożona }\end{array}$ & zagrożona & $\begin{array}{l}\text { ponad } 50 \% \text { powierzchni zlewni zajmują } \\
\text { tereny rolne, długotrwały proces inwe- } \\
\text { stycyjny, silne zmiany morfologiczne, } \\
\text { budowle piętrzące }\end{array}$ \\
\hline 499 & $\begin{array}{l}\text { Warta od Kopli do } \\
\text { Cybiny. Odcinek } \\
\text { Luboń-Poznań }\end{array}$ & $\begin{array}{l}\text { silnie } \\
\text { zmieniona }\end{array}$ & $\begin{array}{l}\text { słaby/ } \\
\text { zagrożona }\end{array}$ & niezagrożona & $\begin{array}{l}\text { silne zmiany morfologiczne, obszar silnie } \\
\text { zurbanizowany }\end{array}$ \\
\hline 500 & $\begin{array}{l}\text { Warta od Cybiny do } \\
\text { Różanego Potoku. } \\
\text { Odcinek Poznań- } \\
\text { Koziegłowy }\end{array}$ & $\begin{array}{l}\text { silnie } \\
\text { zmieniona }\end{array}$ & $\begin{array}{l}\text { słaby/ } \\
\text { zagrożona }\end{array}$ & zagrożona & $\begin{array}{l}\text { silne zmiany morfologiczne, regulacje na } \\
\text { rzece, obszar silnie zurbanizowany }\end{array}$ \\
\hline
\end{tabular}




\begin{tabular}{|c|c|c|c|c|c|}
\hline \multirow[t]{2}{*}{$\begin{array}{l}\text { Nr jcwp* } \\
\text { Surface } \\
\text { water } \\
\text { body } \\
\text { number* }\end{array}$} & \multirow[t]{2}{*}{$\begin{array}{l}\text { Nazwa zlewni - kod } \\
\text { Catchment } \\
\text { name-code }\end{array}$} & \multirow[t]{2}{*}{$\begin{array}{l}\text { Status } \\
\text { jcwp } \\
\text { Surface } \\
\text { water body } \\
\text { status }\end{array}$} & \multicolumn{2}{|c|}{$\begin{array}{l}\text { Ocena stanu (potencjału)/ } \\
\text { ryzyka nieosiągnięcia celów } \\
\text { środowiskowych } \\
\text { Assessment of the potential } \\
\text { of the risk of failure to achieve } \\
\text { environmental objectives }\end{array}$} & \multirow[t]{2}{*}{$\begin{array}{l}\text { Czynniki i działania zagrażające } \\
\text { Hazardous factors and activities }\end{array}$} \\
\hline & & & $2011^{* *}$ & $2014^{\star \star \star}$ & \\
\hline 501 & $\begin{array}{l}\text { Warta od Różanego } \\
\text { Potoku do Dopływu } \\
\text { z Uchorowa. Odci- } \\
\text { nek Koziegłowy- } \\
\text { Gołaszyn }\end{array}$ & $\begin{array}{l}\text { silnie } \\
\text { zmieniona }\end{array}$ & $\begin{array}{l}\text { zły/ } \\
\text { zagrożona }\end{array}$ & niezagrożona & $\begin{array}{l}\text { silne zmiany morfologiczne (regula- } \\
\text { cje), długotrwały proces inwestycyjny, } \\
\text { prawie } 50 \% \text { powierzchni zlewni zajmują } \\
\text { tereny rolne, wysoki wskaźnik gęstości } \\
\text { zaludnienia }\end{array}$ \\
\hline 502 & $\begin{array}{l}\text { Warta od Dopływu } \\
\text { z Uchorowa do } \\
\text { Wełny. } \\
\text { Odcinek Gołaszy- } \\
\text { Oborniki }\end{array}$ & $\begin{array}{l}\text { silnie } \\
\text { zmieniona }\end{array}$ & $\begin{array}{l}\text { zły/ } \\
\text { zagrożona }\end{array}$ & zagrożona & $\begin{array}{l}\text { ponad } 60 \% \text { powierzchni zlewni zajmują } \\
\text { tereny rolne, obszar silnie zurbanizowany, } \\
\text { długotrwały proces inwestycyjny, zmiany } \\
\text { morfologiczne, budowle piętrzące na } \\
\text { rzece }\end{array}$ \\
\hline 503 & $\begin{array}{l}\text { Warta od Wełny } \\
\text { do Samy. Odcinek } \\
\text { Oborniki-Zielona } \\
\text { Góra }\end{array}$ & $\begin{array}{l}\text { silnie } \\
\text { zmieniona }\end{array}$ & $\begin{array}{l}\text { zły/ } \\
\text { zagrożona }\end{array}$ & niezagrożona & $\begin{array}{l}\text { ponad } 40 \% \text { powierzchni użytkowanych } \\
\text { jest rolniczo, znaczne zmiany } \\
\text { morfologiczne (regulacje) }\end{array}$ \\
\hline
\end{tabular}

\section{Objaśnienia:}

* Numer jcwp wg RZGW w Poznaniu, zgodny z numeracją na ryc. 5.

** Na podstawie charakterystyki jednolitych części wód (Plan gospodarowania wodami na obszarze dorzecza Odry, M.P. 2011 nr 40 poz. 451).

*** Na podstawie projektu aktualizacji Planu gospodarowania wodami na obszarze dorzecza Odry (KZGW, 2015).

\section{Explanations:}

* The surface water body number as per the Poznań Regional Water Management Authority, corresponding to the numbering in Fig. 5.

** Based on the Surface Water Bodies Analysis (Waters management plan in the Oder basin area, M.P. 2011 no. 40, item 451).

*** Based on the Update Plan for the Waters management plan in the Oder basin area (National Water Management Authority, 2015).

Analiza charakteru działań technicznych planowanych do realizacji na odcinku doliny Warty między Koninem a Obornikami w okresie 2016-2021 wykazała, że wysoki priorytet nadano działaniom, które ze względu na charakter zlewni oraz rodzaj przeważającego zagrożenia powinny zostać wykonane w pierwszej kolejności dla możliwie szybkiego ograniczenia zagrożenia powodziowego. Do zadań tych należą: utrzymanie w odpowiednim stanie technicznym istniejących wałów przeciwpowodziowych, budowa i kolejnych oraz modernizacja budowli ochronnych pasa technicznego, regulacja i prace utrzymaniowe rzek i potoków, a także poprawa stanu technicznego obecnej infrastruktury przeciwpowodzio- 
wej (tab. 2). Równolegle z działaniami o wysokim priorytecie (hotspoty: Golina i Poznań-Luboń) lub natychmiast po ich zakończeniu przewidziane zostały do realizacji działania istotne $\mathrm{w}$ dłuższej perspektywie czasowej, którym przypisano priorytet średni. Zaliczono do nich m.in. działania techniczne związane z ochroną i zwiększaniem retencji leśnej oraz retencji na obszarach rolniczych i zurbanizowanych. W wielu opracowaniach wskazuje się na potrzebę zwiększenia zdolności retencyjnej zlewni jako właściwej strategii ograniczania zagrożenia powodziowego (Mrozik, Przybyła 2013; Wagner i in. 2014). Zdaniem Bernaciaka i in. (2015), którzy przeprowadzili identyfikację działań dotyczących małej retencji wodnej podejmowanych przez gminy nadwarciańskie w ramach programów ochrony środowiska, nie stanowi ona priorytetu w zakresie ochrony i gospodarowania wodami oraz ochrony przeciwpowodziowej.

Do działań o priorytecie niskim, planowanych do realizacji w dolinie Warty na odcinku Koło-Oborniki zaklasyfikowano inwestycje najmniej skuteczne przy uwzględnieniu charakteru zagrożenia lub trudne do zastosowania w danej zlewni ze względu na jej właściwości, np. budowa kanałów ulgi oraz budowa i odtwarzanie systemów melioracji. Do działań ograniczających wrażliwość terenów zagrożonych powodzią zaliczono z kolei: powstrzymanie dalszego zagospodarowywania, ograniczenie obecnego użytkowania terenów narażonych na bezpośrednie oddziaływanie wód powodziowych, racjonalne zagospodarowywanie terenów zagrożonych na skutek awarii obwałowania oraz wdrożenie instrumentów prawno-ekonomicznych wspomagających realizację podejmowanych przedsięwzięć.

Jak wynika $z$ analiz prowadzonych na pradolinnym i przełomowym odcinku doliny Warty, działania techniczne wskazane do realizacji oprócz celu związanego z ograniczeniem zagrożenia powodziowego mają też na celu utrzymanie parametrów koryta oraz istniejących budowli regulacyjnych (ryc. 4). Brak realizacji działań regulacyjnych w korycie Warty oraz w kanałach ulgi wiązałby się z narastającym zamuleniem koryta i wzrostem zagrożenia powodziowego, zwłaszcza na terenach miast (PZRP dla RWW 2015). Zmiana parametrów hydraulicznych rzeki poprzez wykonanie np. przekopów przyczynia się do zwiększenia prędkości przepływu wody oraz zmniejszenia ilości odkładanego rumowiska, co ma istotne znaczenie na odcinkach, gdzie występują zatory lodowe i śryżowe mogące powodować powódź zatorową (np. rejon Koła, Śremu). Problem wpływu regulacji rzek na stan zagrożenia powodziowego jest szczególnie istotny w przypadku większych systemów rzecznych o wysokim ryzyku powodziowym. Rzeki cechują się zróżnicowanym zaawansowaniem prac regulacyjnych wzdłuż ich biegu, czego konsekwencją jest odmiennie kształtujące się zagrożenie powodziowe w poszczególnych ich odcinkach. Dodatkowy wpływ wywierają cechy zlewni, a także przemodelowanie koryta rzeki wskutek regulacji i związane z tym zmiany ustroju rzecznego (Łajczak 2006; Żelazo 2006; Korpak 2008; Żelazo, Popek 2014). Zdaniem Kledyńskiego (2011) w dolinach rzecznych, ze względu na 
sprzeczne interesy związane $\mathrm{z}$ jednej strony z ochroną wód oraz obszarów Natura 2000, a z drugiej - z zarządzaniem ryzykiem powodziowym, realizowane jest tzw. zarządzanie konfliktem.

Regulacja Warty i jej kanałów ulgi oraz budowa lub przebudowa urządzeń regulacyjnych na rzece, przy uwzględnieniu charakteru inwestycji i szerokiego zakresu ingerencji w koryto rzeki, zakwalifikowane zostały do działań, które mogą powodować nieosiągnięcie lub pogorszenie dobrego stanu lub potencjału ekologicznego wód (tab. 3). Potwierdzeniem jest m.in. status jednolitych części wód powierzchniowych wyróżnionych na badanym odcinku biegu Warty jako silnie zmienione jcwp oraz przypisane im ryzyko nieosiągnięcia dobrego potencjału ekologicznego wód. Wśród przyczyn złego stanu wskazane zostały m.in. silne zmiany morfologiczne koryta rzecznego rejestrowane jako efekt prowadzenia prac regulacyjnych w korycie i działania budowli piętrzących. Prace utrzymaniowe prowadzone na rzekach bardzo często niszczą siedliska, w których występują chronione gatunki roślin i zwierząt oraz gatunki ryb o znaczeniu gospodarczym, co może skutkować brakiem możliwości poprawy jakości wód i osiągnięcia, w perspektywie kolejnych lat 2021 i 2027 (po roku 2015), dobrego stanu lub potencjału ekologicznego wód.

Zgodnie z rozporządzeniem w sprawie warunków korzystania z wód regionu wodnego Warty (Rozporæqdzenie... 2014) stanowi ona ciek szczególnie istotny dla zachowania ciągłości morfologicznej, które jest niezbędne dla spełnienia przez elementy biologiczne wymagań określonych dla dobrego stanu lub potencjału ekologicznego jednolitych części wód powierzchniowych oraz zachowania funkcji najważniejszych korytarzy migracyjnych ryb. Istotne znaczenie ma charakter działań technicznych z zakresu ograniczenia zagrożenia powodziowego wdrażany do realizacji w tej części doliny Warty, która pokrywa się z zasięgiem obszarowych form ochrony przyrody. Uwzględniając skalę wpływu planowanych działań na elementy środowiskowe, zaliczono je do grupy oddziaływań znaczących, tzw. działań niekorzystnych środowiskowo. Algorytm akceptowalności (udatności) środowiskowej przedsięwzięć planowanych do realizacji na poziomie zlewni uwzględnia działania: korzystne, umiarkowanie korzystne i niekorzystne środowiskowo (PZRP dla RWW 2015) (ryc. 6).

Do działań niekorzystnych środowiskowo zaliczono inwestycje, które stanowią zagrożenie dla osiągnięcia celów ochrony wód w rozumieniu Ramowej dyrektywy wodnej. Są to przedsięwzięcia, które mogą wpływać na przedmiot i cele ochrony obszarowych form ochrony przyrody oraz istotnie ograniczać funkcjonalność korytarzy ekologicznych. Analizy wykazały, że podstawowe uwarunkowania środowiskowe lokalizacji inwestycji przeciwpowodziowych w dolinie Warty determinują zasadniczo cele dla obszarów chronionych Natura 2000, które zajmują znaczne fragmenty jej doliny na odcinku między Koninem a Obornikami (ryc. 2). W ocenie oddziaływania planowanych inwestycji na obszary chronione uwzględniono przede 


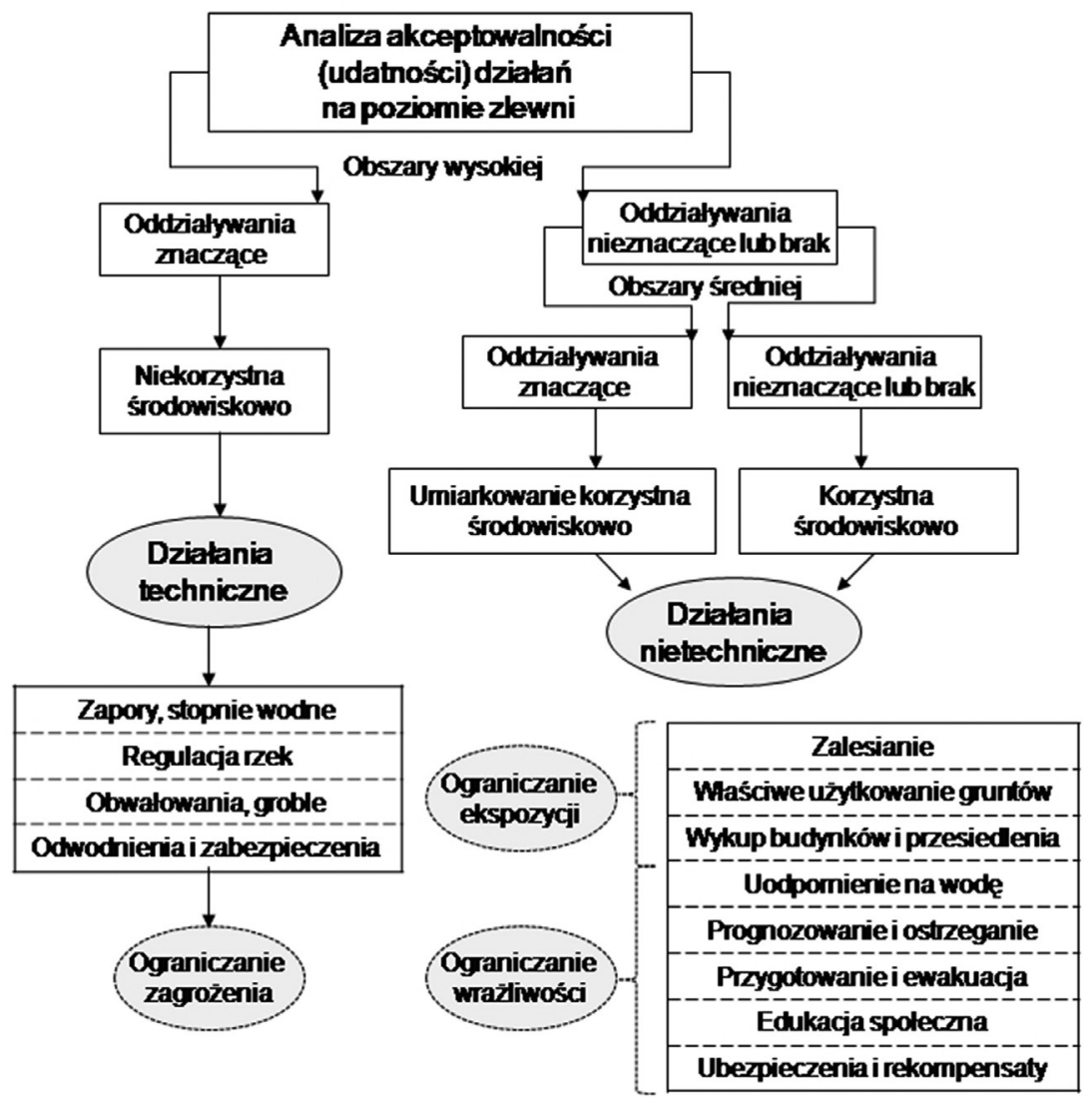

Fig. 6. Algorytm akceptowalności (udatności) środowiskowej przedsięwzięć planowanych do realizacji na poziomie zlewni (na podstawie PZRP dla RWW, zmodyfikowany)

Fig. 6. Environmental acceptability (success rate) algorithm for enterprises slated for execution at the catchment level (based on the Flood Risk Management Plans for the Warta Water Region, modified)

wszystkim położenie przedsięwzięcia względem granic obszaru objętego ochroną, wyróżniając zarówno obszary, na których planowana inwestycja się znajduje (ryc. 4), jak i zlokalizowane poza granicami przedsięwzięć, ale znajdujące się w zasięgu jej oddziaływania. W przypadku 16 działań technicznych planowanych do realizacji w dolinie Warty (tab. 2), określono możliwy wpływ inwestycji na 
realizację celów związanych z funkcjonowaniem obszarów Natura 2000, za które uznano przede wszystkim: zniszczenie siedlisk przyrodniczych i gatunków na trasie odbudowywanego wału oraz u podnóża rozbudowywanego wału od strony międzywala, a także emisję hałasu, która może powodować płoszenie ptaków. Działania inwestycyjne niekorzystne środowiskowo są realizowane tylko w sytuacji braku możliwości wskazanie alternatywnego wariantu, korzystniejszego z punktu widzenia celów ochrony wód oraz obszarów Natura 2000.

Zgodnie z przyjętym algorytmem akceptowalności środowiskowej, stopień akceptowalności umiarkowanie korzystny i korzystny środowiskowo przypisano działaniom inwestycyjnym w zlewni, których wpływ na poszczególne elementy oceny nie jest znaczący, może zostać skutecznie zminimalizowany lub nie stwierdzono możliwości oddziaływania. Działania z tej grupy nie stanowią zagrożenia dla osiągnięcia celów ochrony wód oraz dla funkcjonowania obszarów Natura 2000 i korytarzy ekologicznych w rozumieniu Ramowej dyrektywy wodnej (Dyrektywa 2000/60/WE). Działania nietechniczne mają charakter wspomagający, tzn. ich realizacja nie jest wystarczająca do odpowiedniego ograniczenia ryzyka powodziowego, ale jest rekomendowana jako działania korzystne zarówno dla celów ograniczania ryzyka powodziowego, jak i dla środowiska. Doliny rzeczne są obecnie postrzegane w większym stopniu jako strefy o cennych walorach przyrodniczych niż tereny o wysokich walorach gospodarczych, co ukierunkowuje minimalizację ryzyka powodziowego na wykorzystanie środków nietechnicznych lub podejście zintegrowane (Kledyński 2011).

Ograniczanie ekspozycji obszaru na powódź przez wskazanie możliwości użytkowania terenów zalewowych w sposób niewrażliwy na skutki zalania (np. parki, tereny rekreacyjne) zaliczane jest obecnie do najskuteczniejszych sposobów zmniejszania potencjalnych strat powodziowych (Graf 2014b; Graf, Pyszny 2016), również w miastach zlokalizowanych w dolinie Warty na odcinku Konin-Oborniki.

Działania techniczne, podejmowane w dolinie Warty w celu ograniczenia zagrożenia powodziowego, mogą natomiast potencjalnie negatywnie oddziaływać na analizowane komponenty środowiska, przy czym skala ich oddziaływań będzie zróżnicowana m.in. w zależności od formy i zakresu prowadzonych prac, stopnia naturalności doliny rzecznej i obecności obszarów chronionych. Techniczny sposób ograniczania zagrożenia powodziowego zakłada, że szkody powodziowe zostaną zlikwidowane lub istotnie ograniczone poprzez działanie systemu hydrotechnicznego (Graf 2014b). W obrębie uregulowanych i obwałowanych odcinków doliny Warty obserwuje się jednak wielokierunkowe przekształcenia warunków odpływu wód ze zlewni, charakterystyk hydromorfologicznych, warunków ekologicznych i cech krajobrazu (tab. 3). Trzeba podkreślić, że negatywne skutki inwestycji przeciwpowodziowych, które stanowią czynnik ograniczający osiągnięcie podstawowego celu środowiskowego, jakim jest dobry stan lub potencjał ekologiczny jednolitych 
części wód powierzchniowych, należy minimalizować, a ekologiczny sposób ochrony przed powodzią, w celu pełnego zabezpieczenia, wspierać metodami technicznymi (Pierzgalski, Żelazo 2008).

Działania o charakterze technicznym realizowane w dolinie Warty są zgodne z przyjętą strategią „odsunąć powódź od ludzi”, która stanowi kontynuację tradycyjnego, technicznego sposobu ograniczania zagrożenia i ochrony przeciwpowodziowej, środki zaś nietechniczne mają na celu „odsunąć ludzi od powodzi” (Kledyński 2011; Graf 2014b). Koncepcja ta uwzględnia działania ustawodawcze, administracyjne, społeczne oraz politykę ubezpieczeniową, co ma prowadzić do zmniejszenia potencjalnego ryzyka powodziowego w dolinie rzecznej, głównie poprzez zmianę jej zagospodarowania i ograniczenie tzw. zabudowy wrażliwej na zalewanie. Zakłada ona przede wszystkim przystosowanie działalności gospodarczej człowieka do powodzi przede wszystkim poprzez nowe uregulowania prawne uwzględnione w planowaniu przestrzennym, a związane np. z zakazem budowy i prowadzenia jakichkolwiek działań w strefach podatnych na powódź (flood prone areas).

Porównanie elementów strategii zarządzania ryzykiem powodziowym, wdrażanej w dolinie Warty na odcinku między Koninem a Obornikami oraz w pozostałych regionach wodnych w Polsce, wskazuje, że optymalnym wariantem w zakresie redukcji strat powodziowych jest kompilacja działań technicznych i nietechnicznych, co umożliwi realizację założeń Dyrektywy powodziowej w regionie wodnym, a nie tylko w pojedynczej zlewni, oraz celów środowiskowych Ramowej dyrektywy wodnej (Graf 2014b).

\section{Wnioski}

Realizacja celów wodnogospodarczych, zintegrowanych z celami środowiskowymi, przyczynia się do występowania konfliktów o dużym nasileniu. Z punktu widzenia realizacji założeń zawartych w Ramowej dyrektywie wodnej na omawianym odcinku Warty, podobnie jak w całym regionie wodnym Warty, zidentyfikowane zostały istotne problemy dotyczące ryzyka nieosiągnięcia celów środowiskowych w zakresie dobrego stanu, potencjału ekologicznego wód, co było nadrzędnym celem do 2015 r. Analizy wykazały, że jednym z najistotniejszych czynników bezpośrednio wpływających na stan środowiskowy i potencjał ekologiczny wód jest realizacja prac związanych z ograniczaniem ryzyka powodziowego. Odcinek Warty pomiędzy Koninem a Obornikami jest szczególnie narażony na występowanie powodzi. Koncentracja ośrodków miejskich nad rzeką wymaga zapewnienia bezpiecznych warunków dla życia i rozwoju gospodarczego oraz ochrony przed lokalnymi podtopieniami. Multiplikacja czynników determinujących to zagrożenie wymaga ścisłego planowania celów wodnogospodarczych ze szczególnym naciskiem na minimalizację 
ryzyka powodziowego. Realizacja tych założeń przyczynia się często do degradacji środowiska przyrodniczego, w tym szczególnie cennych obszarów Natura 2000, które stanowią nieodłączny element krajobrazowy większych dolin rzecznych, również doliny Warty na badanym odcinku. Wyniki przeprowadzonej analizy wykazały istotne różnice w realizacji celów związanych z zarządzaniem ryzykiem powodziowym i ochroną wód na przełomowym i pradolinnym odcinku doliny Warty. Zaobserwowano wyraźną dominację inwestycji przeciwpowodziowych na odcinku pradolinnym, gdzie zwiększony stopień zagrożenia powodziami może osłabiać realizację celów środowiskowych. Odwrotną sytuację można zaobserwować na odcinku przełomowym Warty, gdzie cele związane z ochroną walorów krajobrazowych i przyrodniczych determinują realizację strategii zarządzania zasobami wodnymi.

W wielu strategiach i planach wskazuje się na minimalizację negatywnych skutków inwestycji przeciwpowodziowych, które stanowią czynnik ograniczający osiągnięcie podstawowego celu środowiskowego, jakim jest dobry stan lub potencjał ekologiczny wód powierzchniowych. Optymalnym kierunkiem działań wodnogospodarczych w przypadku silnie przekształconych i zurbanizowanych dolin rzecznych jest ekologiczny sposób ograniczania zagrożenia i ryzyka powodziowego wspierany metodami technicznymi i nietechnicznymi, co może stanowić element wspomagający integrację systemu zarządzania ryzykiem powodziowym i ochroną zasobów wodnych.

\section{Literatura}

Bernaciak A., Spychała M., Korytowski M., Powolna P., 2015, Mała retencja wodna w programach ochrony Środowiska gmin nadwarciańskich, Inżynieria Ekologiczna, 44, 121-130.

Charakterystyki jednolitych części wód, [w:] Plan gospodarowania wodami na obszarze dorzecza Odry (M.P. $2011 \mathrm{nr} 40$ poz. 451), http://www.poznan.rzgw.gov.pl (24.06.2016).

Dyrektywa 2000/60/WE Parlamentu Europejskiego i Rady z dnia 23 października 2000 r. ustanawiająca ramy wspólnotowego działania w dziedzinie polityki wodnej (Dz.Urz. WE L 327/1 z 22.12.2000, z późn. zm.).

Dyrektywa 2007/60/WE Parlamentu Europejskiego i Rady z dnia 23 października 2007 r. w sprawie oceny ryzyka powodziowego i zarządzania nim (Dz.Urz. UE L/288 z 6.11.2007).

Global Water Partnership, 2000, Integrated Water Resources Management, Background Paper 4, Global Water Partnership Technical Advisory Committee.

Graf R., 2012, Struktura i funkcjonowanie lokalnych systemów krqżenia wód podziemnych na obszarze Wysoczyzny Poznańskiej, Studia i Prace z Geografii i Geologii, 26, Bogucki Wydawnictwo Naukowe, Poznań.

Graf R., 2014a, Præestrzenne zróżnicowanie sptywu powierzchniowego w zlewniach zurbanizowanych na przyktadzie miasta Poznania, [w:] T. Ciupa, R. Suligowski (red.), Woda w mieście, Komisja Hydrologiczna Polskiego Towarzystwa Geograficznego, Instytut Geografii Uniwersytetu Jana Kochanowskiego, Kielce, 59-71. 
Graf R., 2014b, Mitygacja ryzyka powodziowego w Polsce, Monografie Komitetu Gospodarki Wodnej PAN, 20, 2, Warszawa, 247-259.

Graf R., 2015, Zmiany termiki wód Warty w profilu taczqcym pradolinny i przetomowy odcinek doliny (Nowa Wies Podgórna-Śrem-Poznań), [w:] D. Absalon, M. Matysik, M. Ruman (red.), Nowoczesne metody i rozwiqzania w hydrologii i gospodarce wodnej, Monografie Komisji Hydrologicznej PTG, PTG Oddział Katowice, 177-194.

Graf R., Pyszny K., 2016, Zintegrowane zaræqdzanie zasobami wodnymi, [w:] T. Kaczmarek, Ł. Mikuła (red.), Koncepcja Kierunków Rozwoju Przestrzennego Metropolii Poznań, Stowarzyszenie Metropolia Poznań, Centrum Badań Metropolitalnych, Poznań, 59-74.

Grocki R., Czamara W., 2001, Metody ograniczania skutków powodzi, Safege, Wrocław.

Grocki R., Eliasiewicz R., 2001, Zagospodarowanie terenów zalewowych, Safege, Wrocław.

Hydroportal KZGW, http://mapy.isok.gov.pl (20.06.2016).

Kledyński Z., 2011, Ochrona præed powodziq i jej infrastruktura w Polsce, [w:] Awarie budowlane, T. 1. Powodzie w Polsce - zniszczenia i profilaktyka, XXV Konferencja Naukowo-Techniczna, Międzyzdroje 24-27 maja 2011, 243-254.

Kondracki J., 2002, Geografia regionalna Polski, PWN, Warszawa.

Korpak J., 2008, Rola maksymalnych wesbrań w funkcjonowaniu systemów uregulowanych koryt górskich, Landform Analysis, 8, 41-44.

Kowalczak P., 2011, Wodne dylematy urbanizacji, Wydawnictwo PTPN, Poznań.

Kowalczak P., 2015, Zintegrowana gospodarka wodna na obszarach zurbaniwowanych. Podstawy hydrologiczno-środowiskowe, cz. I, ProDruk, Poznań.

Krauze K., Wagner I., 2014, Woda w przestrzeni miejskiej a sintegrowane zarzqdzanie miastem, [w:] T. Bergier, J. Kronenberg, I. Wagner (red.), Woda w mieście. Zrównoważony Rozwój zastosowania, Fundacja Sendzimira, Kraków, 5, 95-114.

KZGW, 2015, Aktualizacja Planu gospodarowania wodami na obszarze dorzecza Odry (2015-2021), http://www.rdw.kzgw.gov.pl (24.06.2016).

Łajczak A., 2006, Regulacja rzeki a sagro:enie powodziowe na przyktadzie Wisty między Skoczowem i Putawami, Infrastruktura i Ekologia Terenów Wiejskich, 4 (1), 197-214.

MasterPlan dla obszaru dorzecza Odry, 2014, http://www.mos.gov.pl (21.04.2016).

Mrozik K., Przybyła Cz., 2013, Mała retencja w planowaniu præestrzennym, ProDruk, Poznań.

Mrozik K., Przybyła Cz., Pyszny K., 2015, Problems of the Integrated Urban Water Management: The case of Poznañ Metropolitan Area (Poland), Rocznik Ochrona Środowiska, 17 (1), 230-245.

Nachlik E., 2006, Ochrona przeciwpowodziowa w powiqzaniu z ochronq walorów przyrodniczych ræek i ich dolin, Infrastruktura i Ekologia Terenów Wiejskich, 4 (1), 47-62.

Narodowa Strategia Gospodarowania Wodami 2030, http://kzgw.gov.pl (25.06.2016).

Pierzgalski E., Żelazo J., 2008, Uwarunkowania i kierunki ochrony præed powodziq, Wiadomości Melioracyjne i Łąkarskie, 1, 15-20.

Plan gospodarowania wodami na obszarze dorzecza Odry (M.P. 2011 nr 40 poz. 451), http:// www.poznan.rzgw.gov.pl (24.06.2016). 
Plan zarządzania ryzykiem powodziowym dla regionu wodnego Warty, 2015, RZGW Poznań, http://www.powodz.gov.pl/pl/plan_view (25.06.2016).

Romanowska M., Trocki M., 2004, Podejscie procesowe w zarzq̨zaniu, Szkoła Główna Handlowa, Warszawa.

Rotko J., 2006, Podstawy prawne gospodarki wodnej, Wyższa Szkoła Informatyki i Zarządzania Copernicus, Wrocław.

Rozporządzenie Dyrektora RZGW w Poznaniu z dnia 2 kwietnia 2014 r. w sprawie warunków korzystania z wód regionu wodnego Warty (Dz.Urz. Wojew. Wlkp. poz. 2129).

Ustawa Prawo wodne (Dz.U. 2001 nr 115 poz. 1229).

Ustawa o zmianie ustawy Prawo wodne oraz niektórych innych ustaw (Dz.U. 2005 nr 130 poz. 1087).

Ustawa o ochronie przyrody z dnia 16 kwietnia 2004 r. (Dz.U. 2004 nr 92 poz. 880).

Wagner I., Januchta-Szostak A., Waack-Zając S.A., 2014, Narzedzia planowania $i$ zarzqdzania strategicznego wodq w præestrzeni miejskiej, [w:] T. Bergier, J. Kronenberg, I. Wagner (red.), Woda w mieście. Zrównoważony Rozwój - zastosowania, Fundacja Sendzimira, Kraków, $5,17-29$.

Wstępna ocena ryzyka powodziowego (WORP), KZGW, http://www.kzgw. gov.pl/pl/wstepnaocena-ryzyka-powodziowego.html (20.06.2016).

Żelazo J., 2006, Renaturyzacja rzek $i$ dolin, Infrastruktura i Ekologia Terenów Wiejskich, 4 (1), 11-31.

Żelazo J., Popek Z., 2014, Podstawy renaturalizacji ræek, Wydawnictwo SGGW, Warszawa.

Renata Graf

Uniwersytet im. Adama Mickiewic»a w Poznaniu

Instytut Geografii Fizycznej i Ksstattowania Środowiska Przyrodniczego

ul. Bogumita Krygowskiego 10, 61-680 Poznań

rengraf@amu.edu.pl

\section{Kamil Jawgiel}

Uniwersytet im. Adama Mickiewicะa w Poznaniu

Instytut Geografii Fizycznej i Kształtowania Środowiska Przyrodniczego

ul. Bogumita Krygowskiego 10, 61-680 Poznań

jawka@amu.edu.pl

Jan Łukasะewicz

Uniwersytet im. Adama Mickiewicza w Poznaniu

Instytut Geografii Fizycznej i Ksztattowania Środowiska Przyrodniczego

ul. Bogumita Krygowskiego 10, 61-680 Poznań

janlu@amu.edu.pl 
